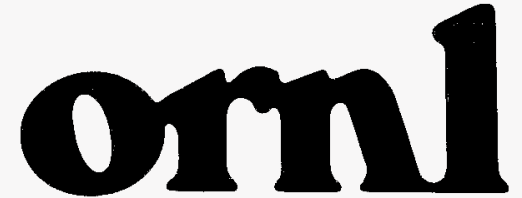

OAK RIDGE NATIONAL LABORATORY

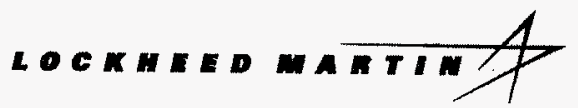

\section{INTERACTIONS OF ZIRCALOY CLADDING WITH GALLIUM: 1998 MIDYEAR STATUS}

\author{
D. F. Wilson \\ J. R. DiStefano \\ J. P. Strizak \\ J. F. King \\ E. T. Manneschmidt
}
RECEIVED
JUL $O 7998$
OSTI


This report has been reproduced directly from the best available copy.

Available to DOE and DOE contractors from the Office of Scientific and Technical Information, P.O. Box 62, Oak Ridge, TN 37831; prices available from (423)576-8401.

Available to the public from the National Technical Information Service, U.S. Department of Commerce, 5285 Port Royal Rd., Springfield, VA 22161.

This report was prepared as an account of work sponsored by an agency of the United States Government. Neither the United States Government nor any agency thereof, nor any of their employees, makes any warranty, express or implied, or assumes any legal liability or responsibility for the accuracy, completeness, or usefulness of any information, apparatus, product, or process disclosed, or represents that its use would not infringe privately owned rights. Reference herein to any specific commercial product, process, or service by trade name, trademark, manufacturer, or otherwise, does not necessarily constitute or imply its endorsement, recommendation, or favoring by the United States Government or any agency thereof. The views and opinions of authors expressed herein do not necessarily state or reflect those of the United States Government or any agency thereof. 


\section{DISCLAIMER}

Portions of this document may be illegible electronic image products. Images are produced from the best available original document. 
ORNL/TM-13625

Metals and Ceramics Division

\title{
INTERACTIONS OF ZIRCALOY CLADDING WITH GALLIUM 1998 MIDYEAR STATUS
}

\author{
D. F. Wilson \\ J. R. DiStefano \\ J. P. Strizak \\ J. F. King \\ E. T. Manneschmidt
}

Date Published: June 1998

NOTICE: This document contains information of a preliminary nature.

It is subject to revision or correction and therefore does not represent a final report.

Prepared for the

U.S. Department of Energy

Office of Fissile Materials Disposition

GA 0102014

Prepared by

OAK RIDGE NATIONAL LABORATORY

Oak Ridge, Tennessee 37831-6285

managed by

LOCKHEED MARTIN ENERGY RESEARCH CORP.

for the

U.S. DEPARTMENT OF ENERGY

under contract DE-AC05-96OR22464 

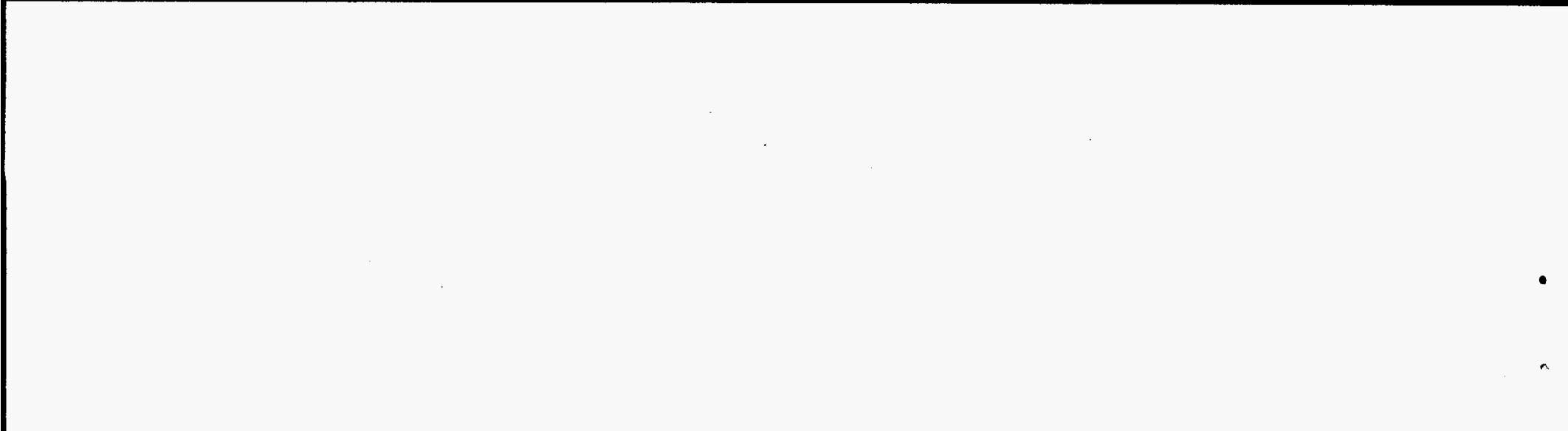

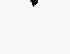


Page

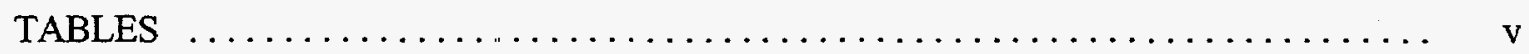

FIGURES $\ldots \ldots \ldots \ldots \ldots \ldots \ldots \ldots \ldots \ldots \ldots \ldots \ldots \ldots \ldots \ldots \ldots \ldots \ldots$ vii

ACRONYMS $\ldots \ldots \ldots \ldots \ldots \ldots \ldots \ldots \ldots \ldots \ldots \ldots \ldots \ldots \ldots \ldots \ldots \ldots \ldots \ldots \ldots \ldots \ldots$

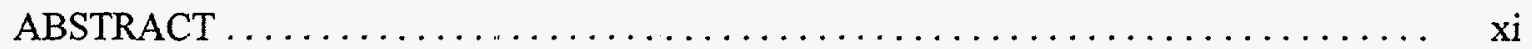

1. INTRODUCTION $\ldots \ldots \ldots \ldots \ldots \ldots \ldots \ldots \ldots \ldots \ldots \ldots \ldots \ldots \ldots \ldots \ldots \ldots \ldots$

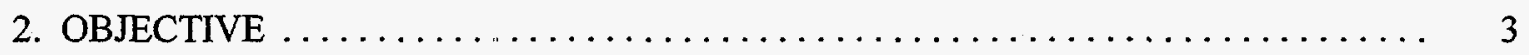

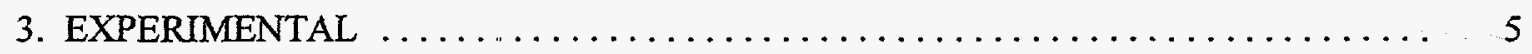

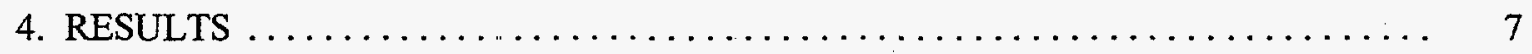

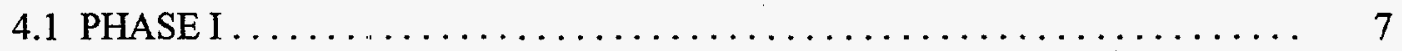

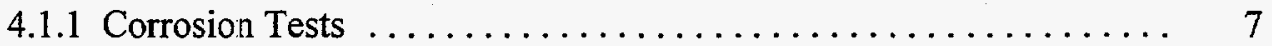

4.1.2 LME Tests . . . . . . . . . . . . . . . . 11

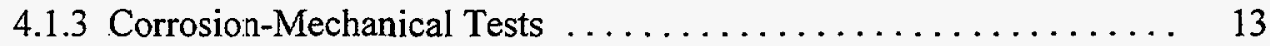

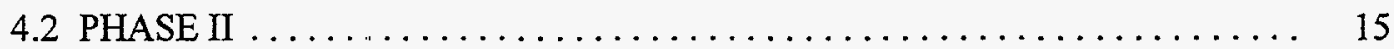

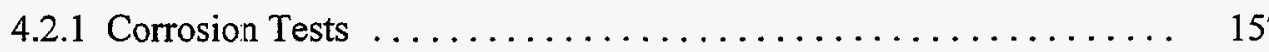

4.2.2 Corrosion-Mechanical Tests $\ldots \ldots \ldots \ldots \ldots \ldots \ldots \ldots \ldots \ldots \ldots \ldots$

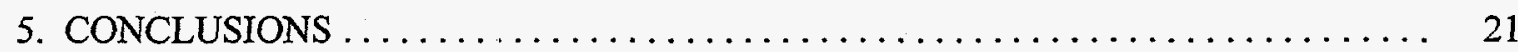

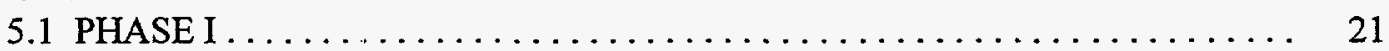

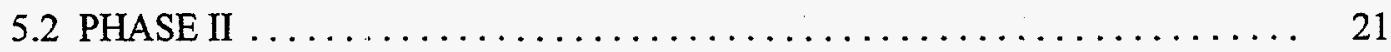

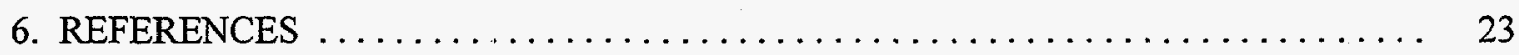

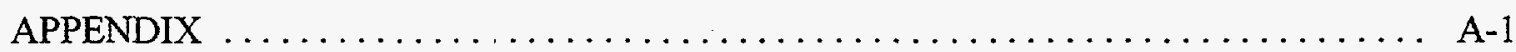





\section{TABLES}

\section{Table}

Page

1 Composition of alloys based on zirconium (weight percent except where noted) ... . 5

A.1 Additional compatibility tests of zirconium/Zircaloy with gallium or $\mathrm{Ga}_{2} \mathrm{O}_{3} \ldots \ldots$ A-1

A.2 Status of corrosion tests of: Zircaloy with gallium metal $\ldots \ldots \ldots \ldots \ldots \ldots \ldots$ A-3

A.3 Status of corrosion tests of: Zircaloy with $\mathrm{Ga}_{2} \mathrm{O}_{3} \ldots \ldots \ldots \ldots \ldots \ldots \ldots \ldots \ldots \ldots \ldots$

A.4 Status of mechanical tests of Zircaloy with gallium metal $\ldots \ldots \ldots \ldots \ldots \ldots \ldots \ldots$ A-4

A.5 Status of corrosion-mechanical tests of Zircaloy with $\mathrm{Ga}_{2} \mathrm{O}_{3} \ldots \ldots \ldots \ldots \ldots \ldots$ A-5 
- 


\section{FIGURES}

Figure

Page

1 Test specimens. a, corrosicn; b, LME; c, corrosion-mechanical;

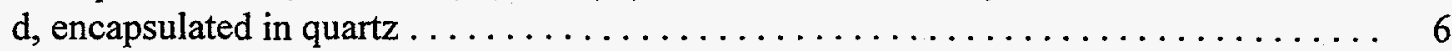

2 No attack of Zircaloy after $700 \mathrm{~h}$ at 30 or $100^{\circ} \mathrm{C} \ldots \ldots \ldots \ldots \ldots \ldots \ldots \ldots \ldots \ldots \ldots \ldots$

3 Cross sections of Zircaloy tubes after corrosion testing with excess gallium (Ga) at $500^{\circ} \mathrm{C}$ for $200 \mathrm{~h}$ showing dimensional distortion $\ldots \ldots \ldots \ldots \ldots \ldots \ldots \ldots \ldots \ldots$

4 Corrosion testing with gallium smaller amounts of gallium $(\mathrm{Ga})$ at $500^{\circ} \mathrm{C}$ for $200 \mathrm{~h} \ldots g$

5 Porosity in $\mathrm{Zr}_{\mathrm{x}} \mathrm{Ga}_{\mathrm{y}}$ formed at $500^{\circ} \mathrm{C}$ in $\mathrm{Zircaloy}$ material $\ldots \ldots \ldots \ldots \ldots \ldots \ldots \ldots$

6 At $300^{\circ} \mathrm{C}$, ICF decreases with decreasing time of exposure $\ldots \ldots \ldots \ldots \ldots \ldots \ldots$

7 ICF continues to decrease as the mass of gallium is decreased $\ldots \ldots \ldots \ldots \ldots \ldots \ldots$

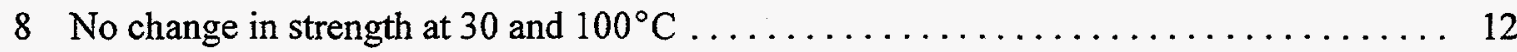

9 No significant difference in ductility at 30 and $100^{\circ} \mathrm{C} \ldots \ldots \ldots \ldots \ldots \ldots \ldots \ldots \ldots \ldots \ldots \ldots$

10 Ductile failure mode at 30 and $100^{\circ} \mathrm{C}$ with and without gallium $\ldots \ldots \ldots \ldots \ldots$

11 No change in strength after reaction with gallium for $30 \mathrm{~h}$ at $300^{\circ} \mathrm{C} \ldots \ldots \ldots \ldots$

12 No significant change in ductility after exposure to gallium for $30 \mathrm{~h}$ at $300^{\circ} \mathrm{C} \ldots \ldots 14$

13 Ductile fracture observed aiter $30 \mathrm{~h}$ at $300^{\circ} \mathrm{C}$ without and with gallium $\ldots \ldots \ldots \ldots$

14 Zircaloy reacts with oxides at $500^{\circ} \mathrm{C}$ to form zirconium oxide $\ldots \ldots \ldots \ldots \ldots \ldots$

15 No significant reaction of Zircaloy with $\mathrm{Ga}_{2} \mathrm{O}_{3}$ after 12 weeks at $300^{\circ} \ldots \ldots \ldots \ldots$

16 Oxide layer present at $500^{\circ} \mathrm{C}$ for all ratios of $\mathrm{Ga}_{2} \mathrm{O}_{3}$ to cerium oxide $\ldots \ldots \ldots \ldots \ldots 17$

$17 \mathrm{Zr}_{\mathrm{x}} \mathrm{Ga}_{\mathrm{y}}$ identified below the zirconium oxide layer after exposure to

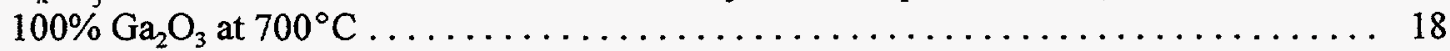

18 No significant change in strength after exposure to $\mathrm{Ga}_{2} \mathrm{O}_{3}$ in cerium oxide $\ldots \ldots \ldots \ldots$

19 No significant change in ductility after exposure to $\mathrm{Ga}_{2} \mathrm{O}_{3}$ in cerium oxide $\ldots \ldots \ldots 19$ 



\section{ACRONYMS}

$\begin{array}{ll}\text { EBW } & \text { electron beam welding } \\ \text { IC } & \text { intermetallic compound } \\ \text { ICF } & \text { intermetallic compound formation } \\ \text { LANL } & \text { Los Alamos National Laboratory } \\ \text { LBW } & \text { laser beam welding } \\ \text { LME } & \text { liquid metal ernbrittlement } \\ \text { LWR } & \text { light-water reactor } \\ \text { MOX } & \text { mixed oxide } \\ \text { ORNL } & \text { Oak Ridge National Laboratory } \\ \text { WG } & \text { weapons grade } \\ \text { wt } & \text { weight }\end{array}$





\begin{abstract}
A program has been implemented to evaluate the effect of gallium in mixed-oxide (MOX) fuel derived from weapons-grade (WG) plutonium on Zircaloy cladding performance. The objective is to demonstrate that low levels of gallium will not compromise the performance of the MOX fuel system in a light-water reactor. The graded, four-phase experimental program was designed to evaluate the performance of prototypic Zircaloy cladding materials against (1) liquid gallium (Phase I), (2) various concentrations of $\mathrm{Ga}_{2} \mathrm{O}_{3}$ (Phase II), (3) centrally heated surrogate fuel pellets with expected levels of gallium (Phase III), and (4) centrally heated prototypic MOX fuel pellets (Phase IV). This status report describes the results of a series of tests for Phases I and II.

Three types of tests are being performed: (1) corrosion, (2) liquid metal embrittlement, and (3) corrosion-mechanical. These tests will determine corrosion mechanisms, thresholds for temperature and concentration of gallium that may delineate behavioral regimes, and changes in the mechanical properties of Zircaloy.

Initial results have generally been favorable for the use of WG-MOX fuel. The MOX fuel cladding, Zircaloy, does react with gallium to form intermetallic compounds at $2300^{\circ} \mathrm{C}$; however, this reaction is limited by the mass of gallium and is therefore not expected to be significant with a low level (parts per million) of gallium in the MOX fuel. Although continued migration of gallium into the initially formed intermetallic compound can result in large stresses that may lead to distortion, this was shown to be extremely unlikely because of the low mass of gallium or gallium oxide present and expected clad temperatures below $400^{\circ} \mathrm{C}$. Furthermore, no evidence for grain boundary perretration by gallium has been observed.
\end{abstract}




\section{INTRODUCTION}

The U.S. Department of Energy has established a dual-track approach to the disposition of plutonium arising from the dismantling of nuclear weapons. Both immobilization and reactorbased mixed-oxide (MOX) fuel technologies are being evaluated. The MOX fuel option requires assessment of the potential impact of gallium (on the order of 1 to $10 \mathrm{ppm}$ ), not present in conventional MOX fuel, on cladding material performance. Two previous reports ${ }^{1,2}$ identified several compatibility issues relating to the presence of gallium in MOX fuel and its possible reaction with fuel cladding.

Gallium initially presert in weapons-grade (WG) plutonium is reduced during processing to produce MOX fuel. After blending the plutonium with uranium, only 1 to $10 \mathrm{ppm}$ gallium is expected in the sintered MOX fuel. Gallium present as gallium oxide $\left(\mathrm{Ga}_{2} \mathrm{O}_{3}\right)$ could be evolved as the suboxide $\left(\mathrm{Ga}_{2} \mathrm{O}\right)$. Migration of the evolved $\mathrm{Ga}_{2} \mathrm{O}$ and diffusion of gallium in the MOX matrix along thermal gradients could lead to locally higher concentrations of $\mathrm{Ga}_{2} \mathrm{O}_{3}$. Thus, while an extremely low concentration of gallium in MOX fuel almost ensures a lack of significant

interaction of gallium with Zircaloy fuel cladding, there remains a small probability that corrosion effects will not be negligible.

A number of reaction routes are possible in this clad-WG-MOX fuel system, including:

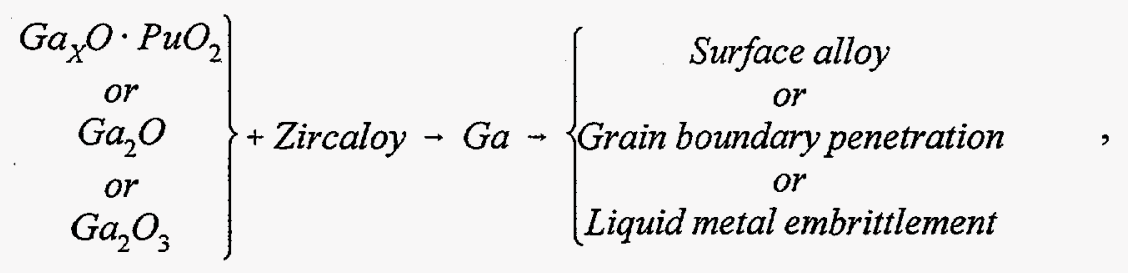

and

$$
\mathrm{Ga}_{2} \mathrm{O}_{3}+\mathrm{ZrO}_{2} \rightarrow\left\{\begin{array} { c } 
{ \text { No reaction } } \\
{ \text { or } } \\
{ \text { Mixed oxide } + \text { crack } + G a }
\end{array} \rightarrow \left\{\begin{array}{c}
\text { Surface alloy } \\
\text { or } \\
\text { Grain boundary penetration } \\
\text { or } \\
\text { Liquid metal embrittlement }
\end{array}\right.\right.
$$


General corrosion in the form of surface alloying from formation of intermetallic compounds between Zircaloy and gallium should be mass limited and, therefore, superficial because of the expected low ratio of gallium to the surface area or volume of the Zircaloy cladding. Although the expected concentration of gallium is low and there is very limited solubility of gallium in zirconium, especially at temperatures below $700^{\circ} \mathrm{C},{ }^{3}$ grain boundary penetration and liquid metal embrittlement (LME) are possible forms of localized corrosion that are also being considered.

One fuel system damage mechanism, pellet clad interaction, has led to some failure of the Zircaloy cladding in light-water reactors (LWRs). This has been attributed to stresses in the cladding and one or more aggressive fission products. Stress corrosion cracking by iodine ${ }^{4,5}$ and LME by cadmium ${ }^{6,7}$ have been reported, and it is known that Zircaloy can be embrittled by some low-melting metals, (e.g., mercury). ${ }^{8}$ LME is a form of environmentally induced embrittlement that can induce cracking or loss of ductility. LME requires wetting and a tensile stress, but it does not require corrosion penetration. Experimentally, it has been demonstrated that gallium can cause embrittlement of some alloys (e.g., aluminum) at low temperatures, ${ }^{9}{ }^{10}$ but experiments relative to LME of zirconium by gallium have been limited and inconclusive. ${ }^{11}$

This report describes a series of gallium-cladding compatibility tests aimed at establishing confidence that low levels of residual gallium in WG-MOX fuel do not affect its long-term compatibility with Zircaloy. In addition, to address damage mechanisms it is important to understand the potential cladding interactions and the available safety margins with respect to gallium concentration. 


\section{OBJECTIVE}

The overall objective of this task is to demonstrate that small concentrations of gallium in MOX fuel will not compromise the performance of the fuel system in an LWR. Although possible mechanisms for gallium interaction with Zircaloy have been identified, ${ }^{1,2}$ no significant data exist that demonstrate whether such reactions actually occur under LWR conditions and whether these reactions have any significant effects on cladding performance. In the present program, a graded, experimental approach is being pursued to determine whether the low levels of gallium will result in fuel system damage. This approach is divided into four phases. In Phase I, laboratory tests were conducted on three prototypic Zircaloy cladding materials in liquid gallium. Three types of tests were used: (1) corrosion, (2) LME, and (3) corrosion-mechanical. LME tests consist of slow strain rate, constant extension rate tensile tests in gallium metal at low temperature $\left(30\right.$ and $\left.100^{\circ} \mathrm{C}\right)$. Corrosion-mechanical tests consist of first exposing the Zircaloy with gallium metal and then conducting a tensile test to evaluate corrosion product effects. Although these Phase I tests conditions (much higher relative amount of gallium compared to that in a fuel rodlet) are not representative of WG-MOX, they provide limiting boundary conditions for mechanistic studies. The test matrices for the Phase I tests are shown in the Appendix.

In Phase II, two of the previously mentioned types of tests, corrosion and corrosionmechanical, were conducted with the three cladding materials in contact with $\mathrm{Ga}_{2} \mathrm{O}_{3}$. In each type of test, four concentrations of $\mathrm{Ga}_{2} \mathrm{O}_{3}$ in $\mathrm{Ce}_{2} \mathrm{O}_{3}$ (surrogate for plutonium dioxide) were evaluated: $100,1,0.2$, and 0.1 weight (wt) \%. Although these levels of $\mathrm{Ga}_{2} \mathrm{O}_{3}$ are all considerably higher than those possible in a sintered MOX pellet, ${ }^{12}$ they can be used to determine the types of reactions that could occur, and, like Phase I tests, they represent a nonconservative evaluation of $\mathrm{Ga}_{2} \mathrm{O}_{3}$ effects in this screening test phase. The test matrices for Phase II tests are shown in the Appendix.

Phase III tests will expose cladding material to centrally heated surrogate fuel pellets that are being manufactured by Los Alamos National Laboratory (LANL). These sintered, annular pellets, $\mathrm{U} / \mathrm{Ce} / \mathrm{Ga} / \mathrm{O}$, will contain less than $0.001 \mathrm{wt} \%$ gallium and will have a density of more than 94\%. The Texas A\&M University Nuclear Science Center designed a nonpressurized test system for the centrally heated pellet tests and will perform the tests. To simulate the thermal gradients across operating reactor pellets and to test for thermally driven gallium diffusion, a small diameter ( $\sim 0.18$-in. outside diameter) electric heater will be inserted into the center of the surrogate pellets. The heater will operate at a temperature of about $1000^{\circ} \mathrm{C}$ with a linear power 
of $15.7 \mathrm{~kW} / \mathrm{m}$. The experiment is configured to produce a nominal cladding-pellet interface temperature of $400^{\circ} \mathrm{C}$. Six 4-in. "rodlets" will be centrally heated and two will be withdrawn periodically for evaluation (the longest time at temperature will be $5000 \mathrm{~h}$ ).

Work related to the planned Phase IV tests has recently been terminated. If conducted, Phase IV tests would be similar to Phase III tests, but prototypic MOX fuel pellets would be used. These tests were to be performed at Oak Ridge National Laboratory (ORNL) with MOX pellets produced by LANL. 


\section{EXPERIMENTAL}

Prototypical LWR cladding materials evaluated included Zircaloy-2, Zircaloy-4, and Zirlo. Compositional ranges for these alloys are presented in Table 1.

Table 1. Composition of alloys based on zirconium (weight percent except where noted)

\begin{tabular}{lcccccc}
\hline Alloy & $\mathrm{Sn}$ & $\mathrm{Fe}$ & $\mathrm{Cr}$ & $\mathrm{Ni}$ & $\mathrm{Nb}$ & $\begin{array}{c}\mathrm{O} \\
(\mathrm{ppm})\end{array}$ \\
\hline Zircaloy-2* $^{*}$ & $1.2-1.7$ & $0.07-0.2$ & $0.05-0.15$ & $0.03-0.08$ & & $1000-1400$ \\
Zircaloy-4 $^{*}$ & $1.2-1.7$ & $0.18-0.24$ & $0.07-0.13$ & & & $1000-1400$ \\
Zirlo $^{\dagger}$ & $0.96-0.98$ & $0.094-0.105$ & $79-83 \mathrm{ppm}$ & & $1.02-1.14$ & $900-1200$ \\
\hline
\end{tabular}

"R. W. Cahn, P. Haasen, and E. J. Kramer, "Materials, Science, and Technology", Vol. 10b, p. 11, Nuclear Materials, Part 2, 1994.

†G. P. Sabol et al., "In-Reactor Corrosion Performance of Zirlo and Zircaloy-4," Zirconium in the Nuclear Industry: Tenth International Symposium, pp. 724-744 in ASTM STP 1245, ed. A. M. Garde and E. R. Bradley, American Society for Testing and Materials, Philadelphia, 1994.

Zircaloy tubing was machined into two different lengths, one for corrosion tests and another for LME or corrosion-mechanical tests, as shown in Fig. 1. End caps with and without threaded ends were machined from Zircaloy bar stock for tensile and corrosion tests, respectively. First, one end cap was welded to the specimen tube, the required quantity of reactant was then added, and the other end cap was welded in place. Because of the reactive nature of the zirconium alloys with oxygen and nitrogen, all welding was performed in either high vacuum using the electron beam welding (EBW) process or in a high-purity, helium-purged welding chamber using the laser beam welding (LBW) process. The completed test specimens for corrosion tests were encapsulated in an evacuated quartz capsule for atmospheric protection during high-temperature exposure (Fig. 1). For mechanical testing above $100^{\circ} \mathrm{C}$, a chamber to provide a protective atmosphere around the test specimens was designed and fabricated. This protective chamber precludes the reaction of zirconium alloys with the ambient oxygen and nitrogen during testing. 


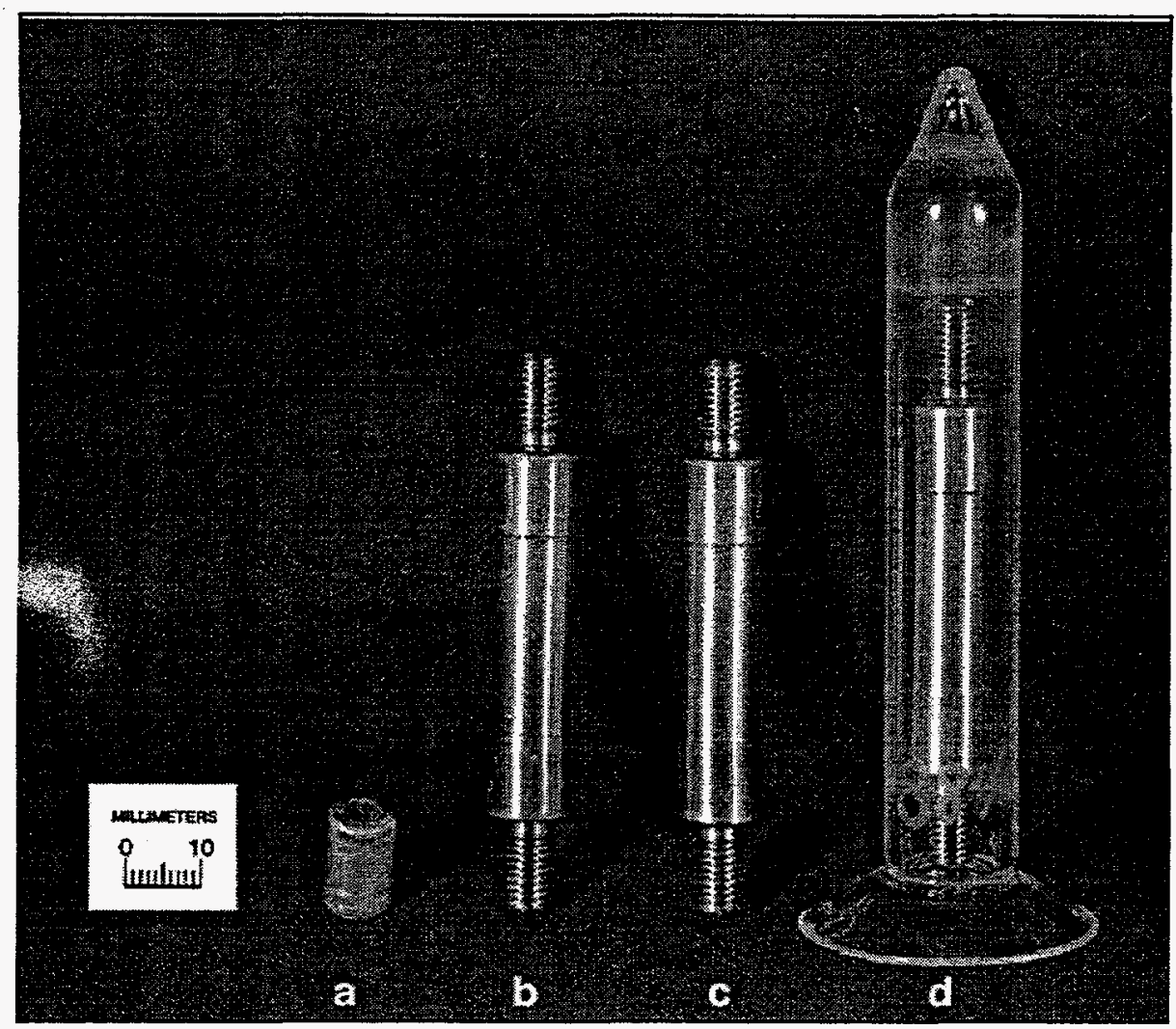

Fig. 1. Test specimens. a, corrosion; b, LME; c, corrosion-mechanical; $\mathrm{d}$, encapsualted in quartz.

In addition to preliminary tests that were performed at 400 and $600^{\circ} \mathrm{C}$, corrosion tests in liquid gallium were conducted at three temperatures $\left(30,100\right.$, and $\left.500^{\circ} \mathrm{C}\right)$ for two exposure times (200 and $700 \mathrm{~h}$ ); those containing $\mathrm{Ga}_{2} \mathrm{O}_{3}$ or surrogate gallium-containing oxide were also tested at three temperatures $\left(300,500\right.$, and $\left.700^{\circ} \mathrm{C}\right)$ for two exposure times ( 6 weeks and 12 weeks). LME tests were conducted in liquid gallium at 30 and $100^{\circ} \mathrm{C}$. Corrosion-mechanical tests in liquid gallium were conducted by first exposing the Zircaloy for $30 \mathrm{~h}$ at $300^{\circ} \mathrm{C}$ and then conducting a room-temperature tensile test. With $\mathrm{Ga}_{2} \mathrm{O}_{3}$, tensile tests were also conducted at room temperature and at the corrosion test temperature after exposure for 6 weeks at 300 and $500^{\circ} \mathrm{C}$. The temperature range brackets the normal, operating clad temperature of $374^{\circ} \mathrm{C}$. Posttest analyses of cross sections of the clad tubes included metallography, fractography, and chemical microprobe. In the case of the corrosion tests, evidence of wall thinning, grain boundary penetration, transgranular attack, and intermetallic compound formation (ICF), when present, were documented. For the mechanical tests (LME or corrosionmechanical), the tensile strength and ductility of specimens tested in the presence of gallium or after exposure to gallium were compared with those tested in the absence of gallium. 


\section{RESULTS}

\subsection{PHASE I}

\subsubsection{Corrosion Tests}

Corrosion tests in liquid gallium were conducted at 30,100 , and $500^{\circ} \mathrm{C}$. After exposure for $700 \mathrm{~h}$ at 30 and $100^{\circ} \mathrm{C}$, none of the Zircaloy materials showed evidence of significant interaction with liquid gallium as indicated by the typical results shown in Fig. 2 . At $500^{\circ} \mathrm{C}$, all of the gallium reacted with Zircaloy to form intermetallic compounds (ICs) of the type $\mathrm{Zr}_{\mathrm{x}} \mathrm{Ga}_{\mathrm{y}}$ after 200 or $700 \mathrm{~h}$. Dimensional distortion of Zircaloy capsules was observed as a result of exposure at $500^{\circ} \mathrm{C}$.

\section{$30^{\circ} \mathrm{C} / 700 \mathrm{~h}$}
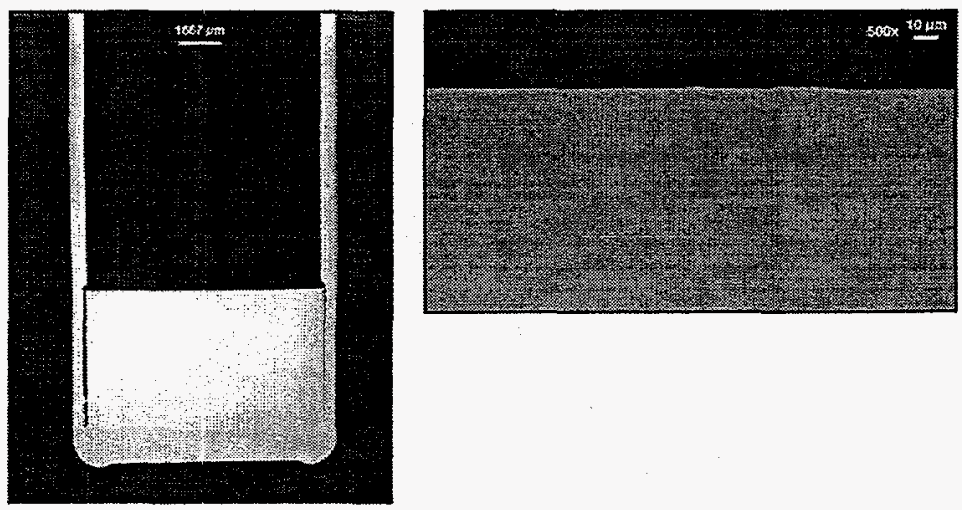

\section{$100^{\circ} \mathrm{C} / 700 \mathrm{~h}$}
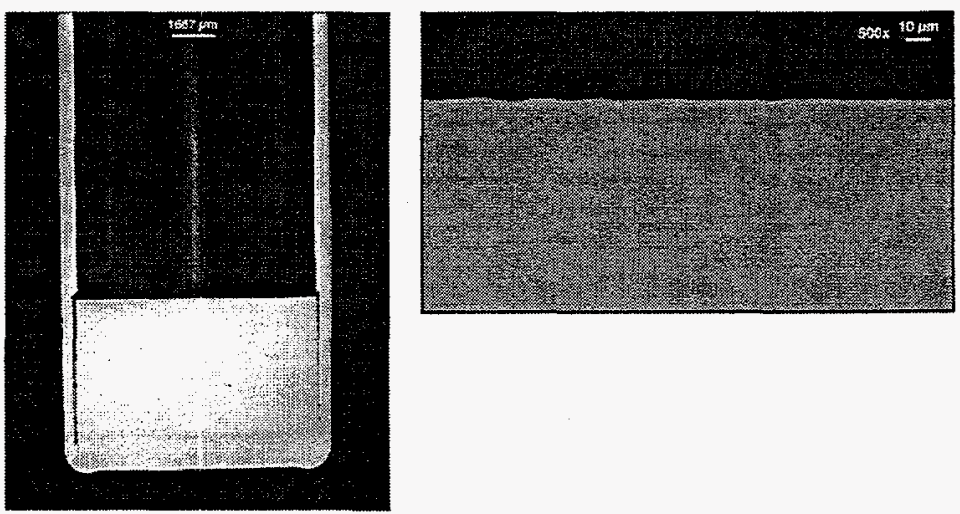

Fig. 2. No attack of Zircaloy after $700 \mathrm{~h}$ at 30 or $100^{\circ} \mathrm{C}$.

Subsequent investigation revealed that the amount of distortion was not related to the end-cap geometry or the internal gas pressure [as determined by whether EBW or LBW (Fig. 3) was used]. However, distortion was a function of the amount of gallium initially in the capsule 


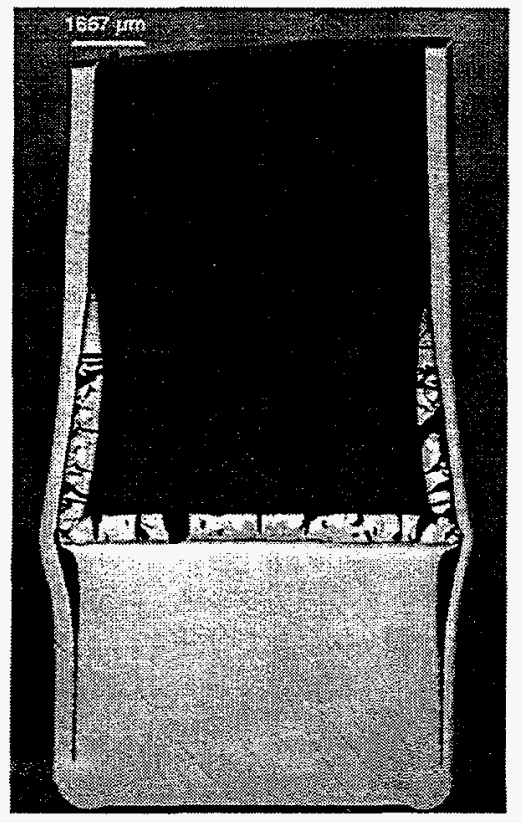

a

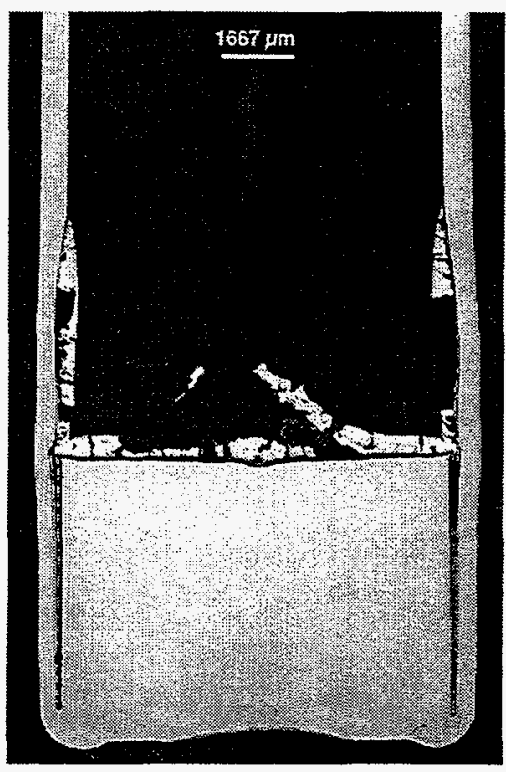

b

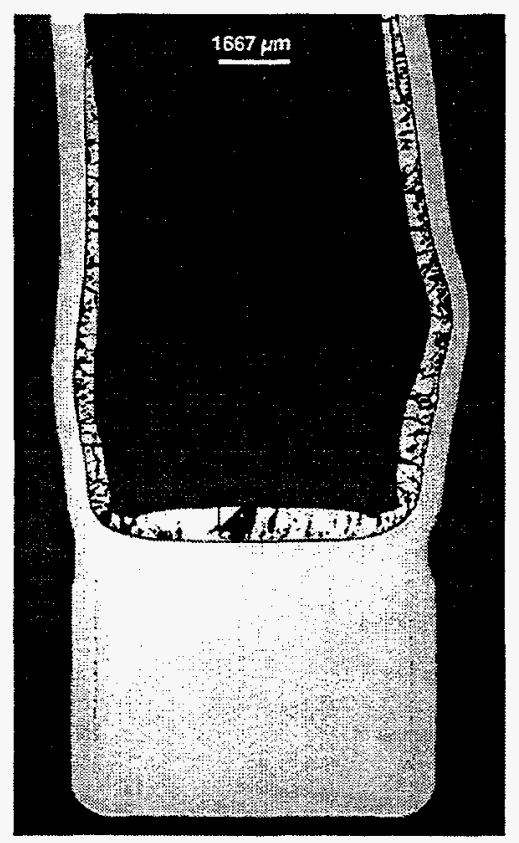

c

Fig. 3. Cross sections of Zircaloy tubes after corrosion testing with excess gallium (Ga) at $500^{\circ} \mathrm{C}$ for $200 \mathrm{~h}$ showing dimensional distortion. Distortion is independent of welding technique. $\mathrm{a}=\mathrm{LBW}, 0.5 \mathrm{~g} \mathrm{Ga} ; \mathrm{b}=\mathrm{EBW}, 0.5 \mathrm{~g} \mathrm{Ga} ; \mathrm{c}=$ no crevice, $0.6 \mathrm{~g} \mathrm{Ga}$. 
even though there was considerable empty space remaining within the capsule at the end of the test (Fig. 4). One of the Zircaloy materials showed little or no distortion even at the highest amounts of gallium, despite the fact that a $\mathrm{Zr}_{\mathrm{x}} \mathrm{Ga}_{\mathrm{y}}$ type of IC formed, as was observed with the other Zircaloy materials. Comparisons of the corrosion product at high magnifications showed some differences in their appearance. Where no distortion occurred, the corrosion product was more porous than when distortion did occur (Fig. 5).

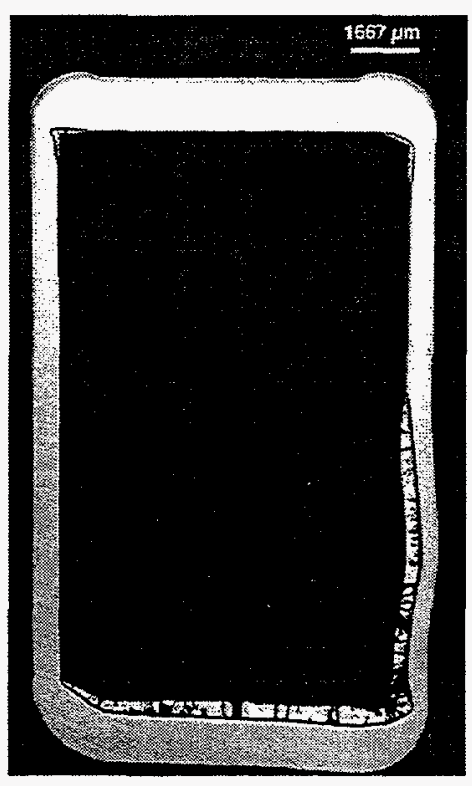

a

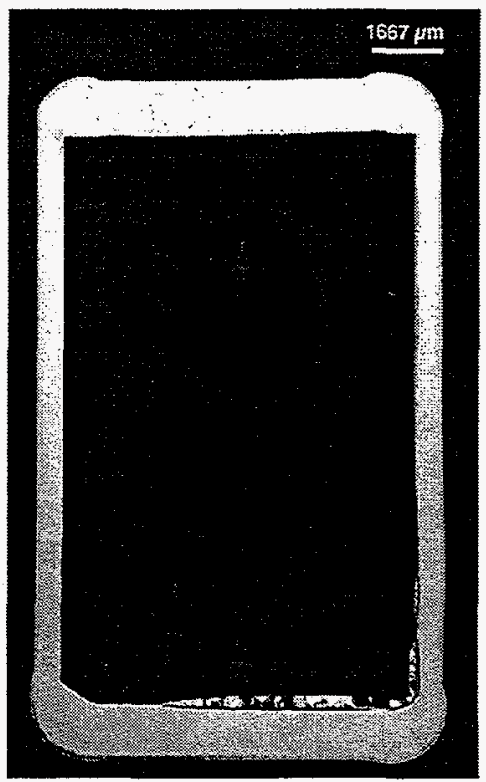

b

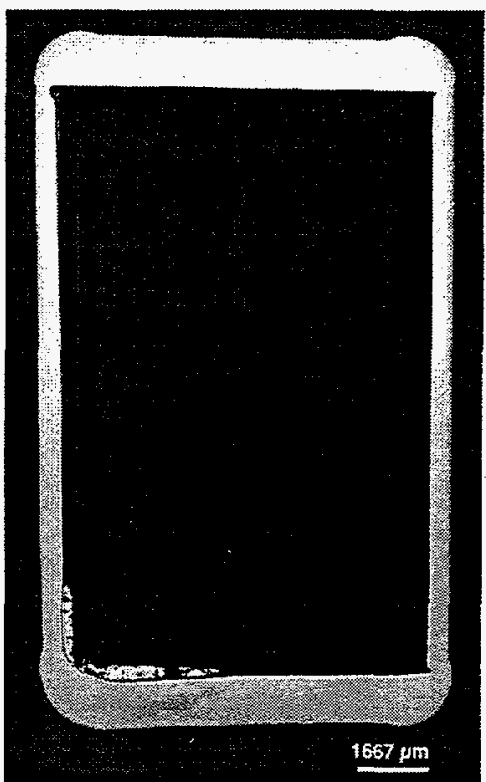

c

Fig. 4. Corrosion testing with smaller amounts of gallium (Ga) at $500^{\circ} \mathrm{C}$ for $200 \mathrm{~h}$. $\mathrm{a}=0.2 \mathrm{~g} \mathrm{Ga}$, shows less dimensional distortion; $\mathrm{b}=0.09 \mathrm{~g} \mathrm{Ga}$, shows minor dimensional distortion; $c=0.05 \mathrm{~g} \mathrm{Ga}$, shows no dimensional distortion.

Further testing at temperatures below $500^{\circ} \mathrm{C}$ showed that, in the susceptible materials, dimensional distortion also occurred at 400 and $350^{\circ} \mathrm{C}$ but was not found after $200 \mathrm{~h}$ at $300^{\circ} \mathrm{C}$. After $200 \mathrm{~h}$ at $300^{\circ} \mathrm{C}$, there was a large amount of unreacted gallium in the capsule at the end of the test. The rate of reaction is very slow at $\leq 300^{\circ} \mathrm{C}$, evidenced by the decreasing amount of corrosion product formed at $\leq 200 \mathrm{~h}$ (Fig. 6). 

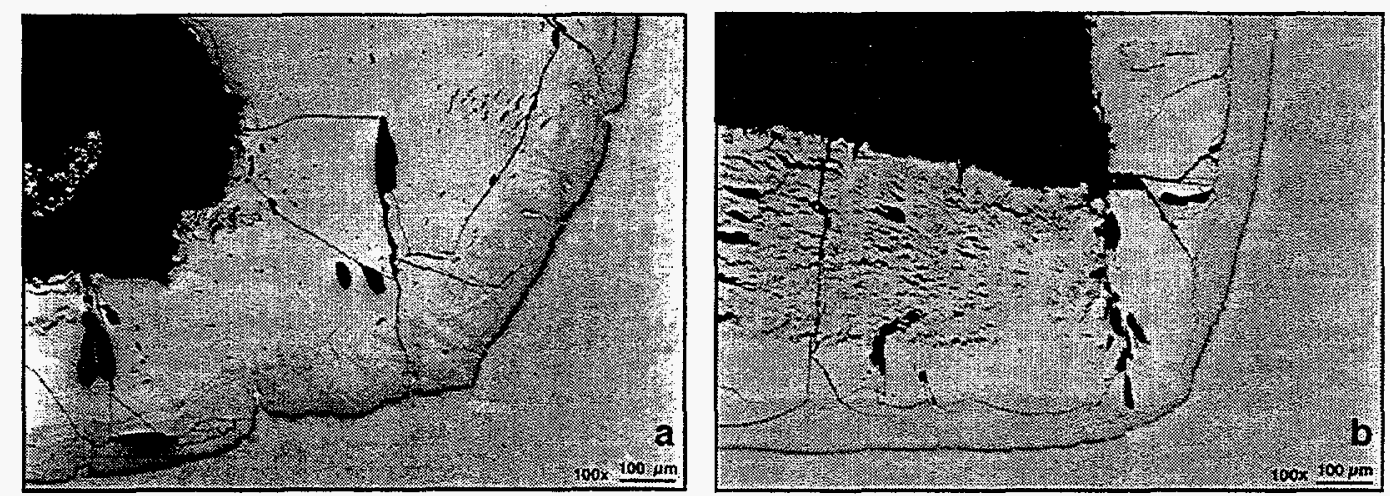

Fig. 5. Porosity in $\mathrm{Zr}_{\mathrm{x}} \mathrm{Ga}_{\mathrm{y}}$ formed at $500^{\circ} \mathrm{C}$ in Zircaloy material. a, material that distorted; $b$, material that did not distort.

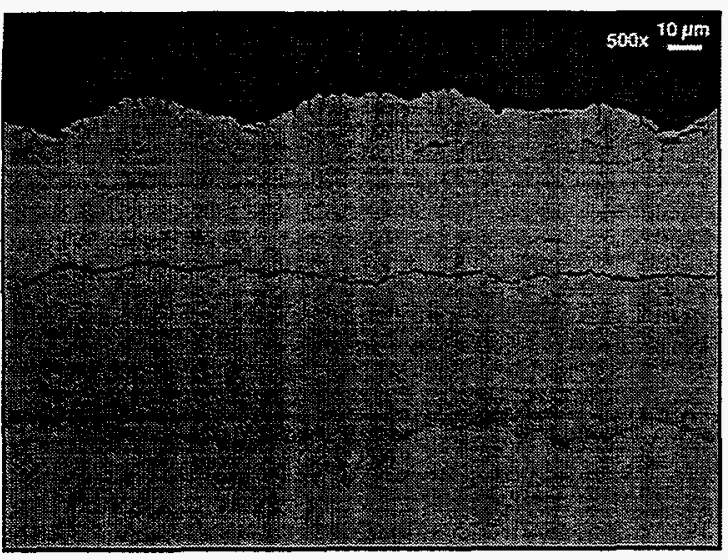

$200 h$

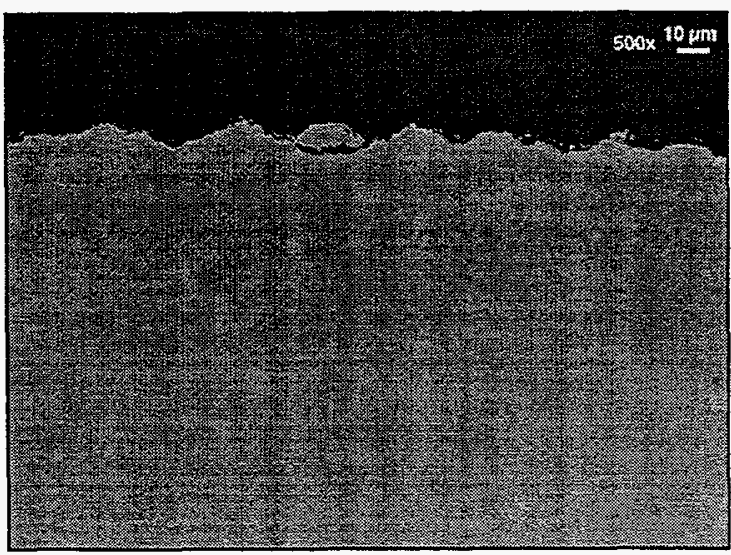

$50 \mathrm{~h}$

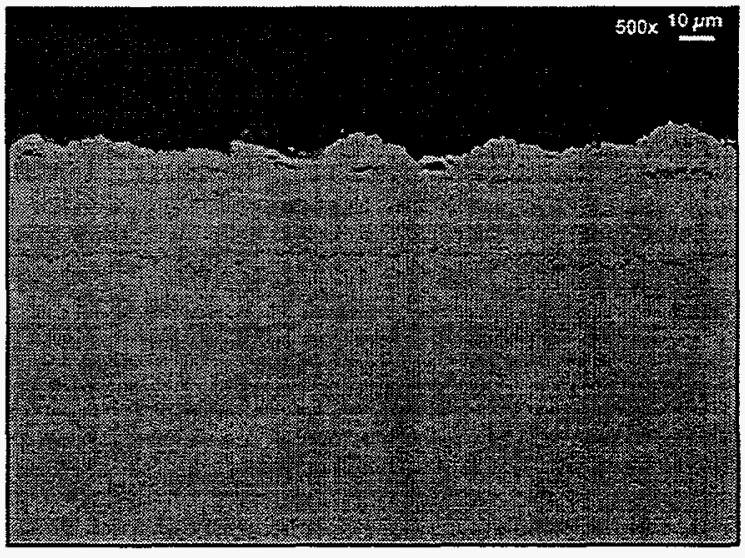

$100 \mathrm{~h}$

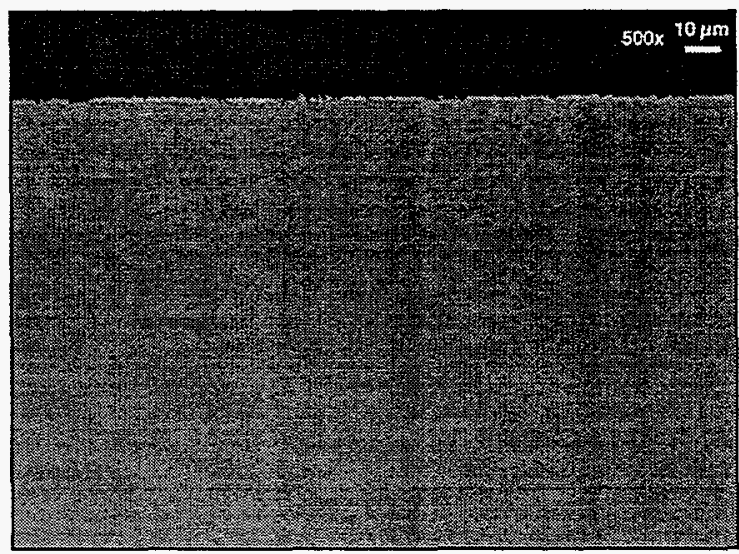

$30 h$

Fig. 6. At $300^{\circ} \mathrm{C}$, ICF decreases with decreasing time of exposure. 
As indicated in Fig. 4, dimensional distortion at $500^{\circ} \mathrm{C}$ was eliminated when smaller amounts of gallium were used in the capsule. In subsequent tests at $500^{\circ} \mathrm{C}$ with even smaller quantities of gallium $(0.025$ to $0.00038 \mathrm{~g})$,

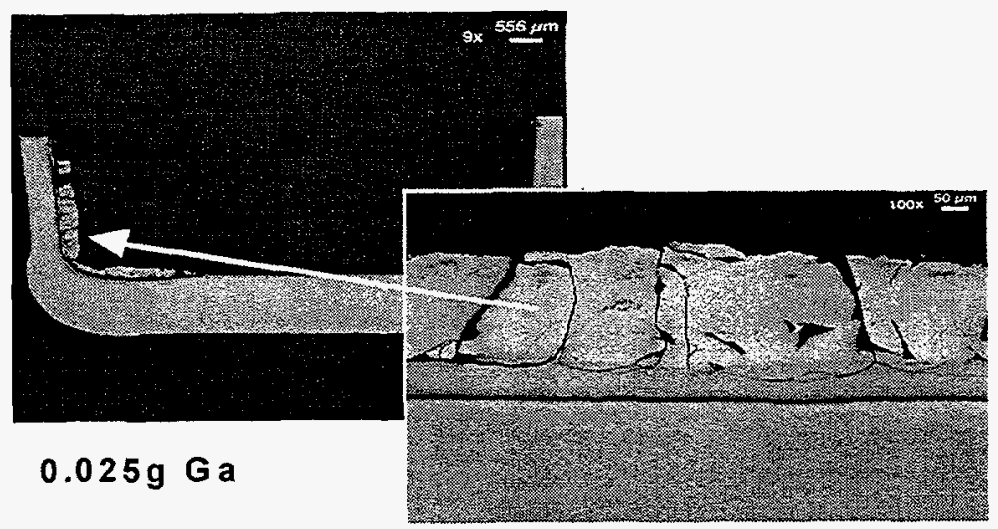
ICF was localized to specific regions where gallium chemically wet the capsule wall but the depth of interaction was quite shallow (Fig. 7).

\subsubsection{LME Tests}

Slow strain rate $\left(3.33 \times 10^{-6} / \mathrm{sec}\right)$, constant extension rate tensile tests were conducted in gallium at 30 and $100^{\circ} \mathrm{C}$, and the results (average of three specimens per condition) are shown in Figs. 8 and 9 . No differences in the tensile properties were found between the tests in gallium compared with those at:

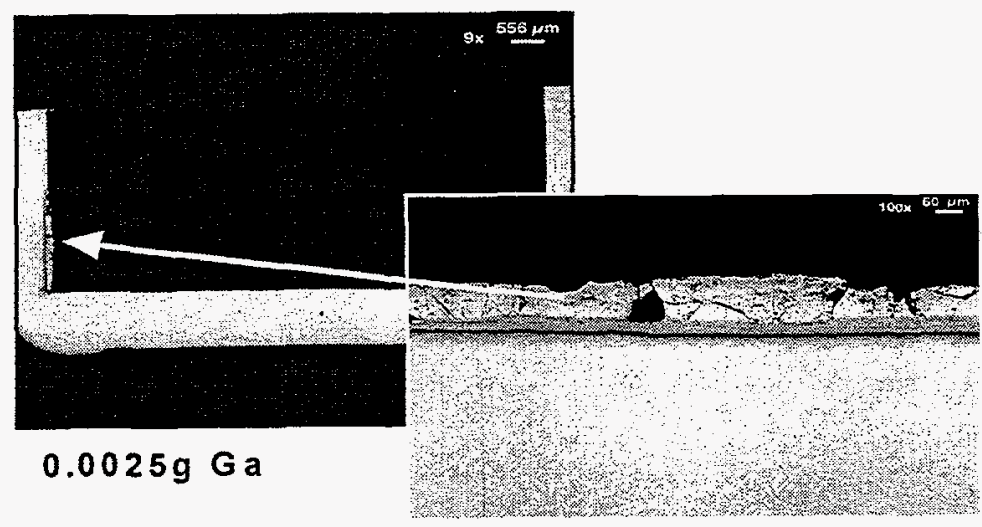
the same temperature without

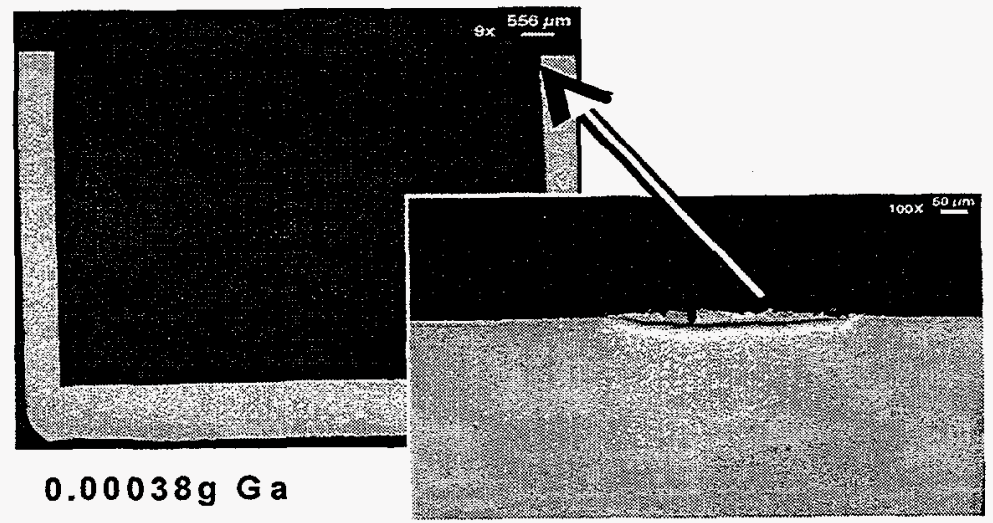

Fig. 7. ICF continues to decrease as the mass of gallium is decreased. gallium. Although there was a small decrease in strength from $100^{\circ} \mathrm{C}$ to $30^{\circ} \mathrm{C}$, this same change occurred without gallium as well. Furthermore, the specimens all failed in a ductile manner, as shown in Fig. 10. 


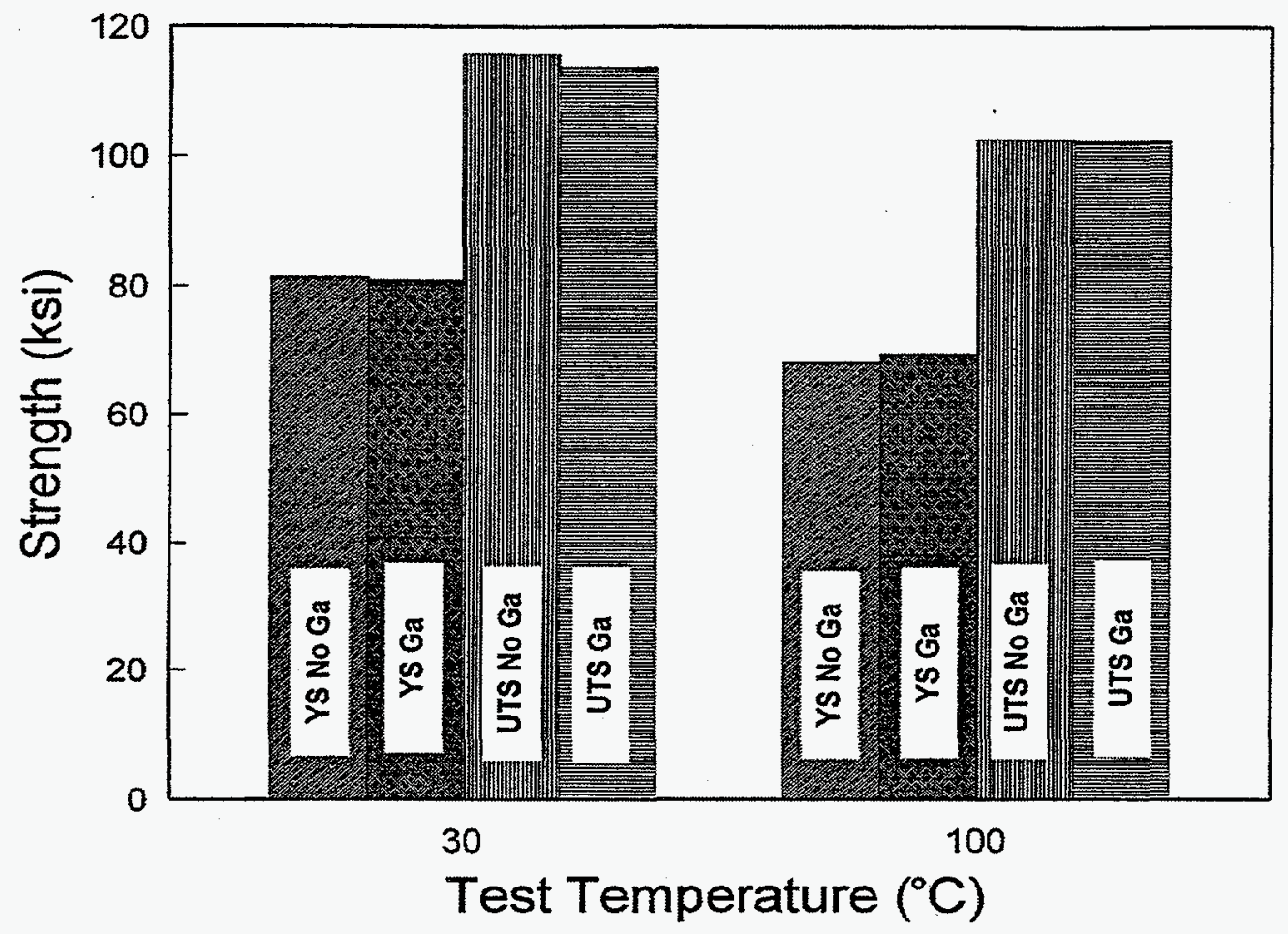

Fig. 8. No change in strength at 30 and $100^{\circ} \mathrm{C}$. YS, yield strength; UTS, ultimate tensile strength.

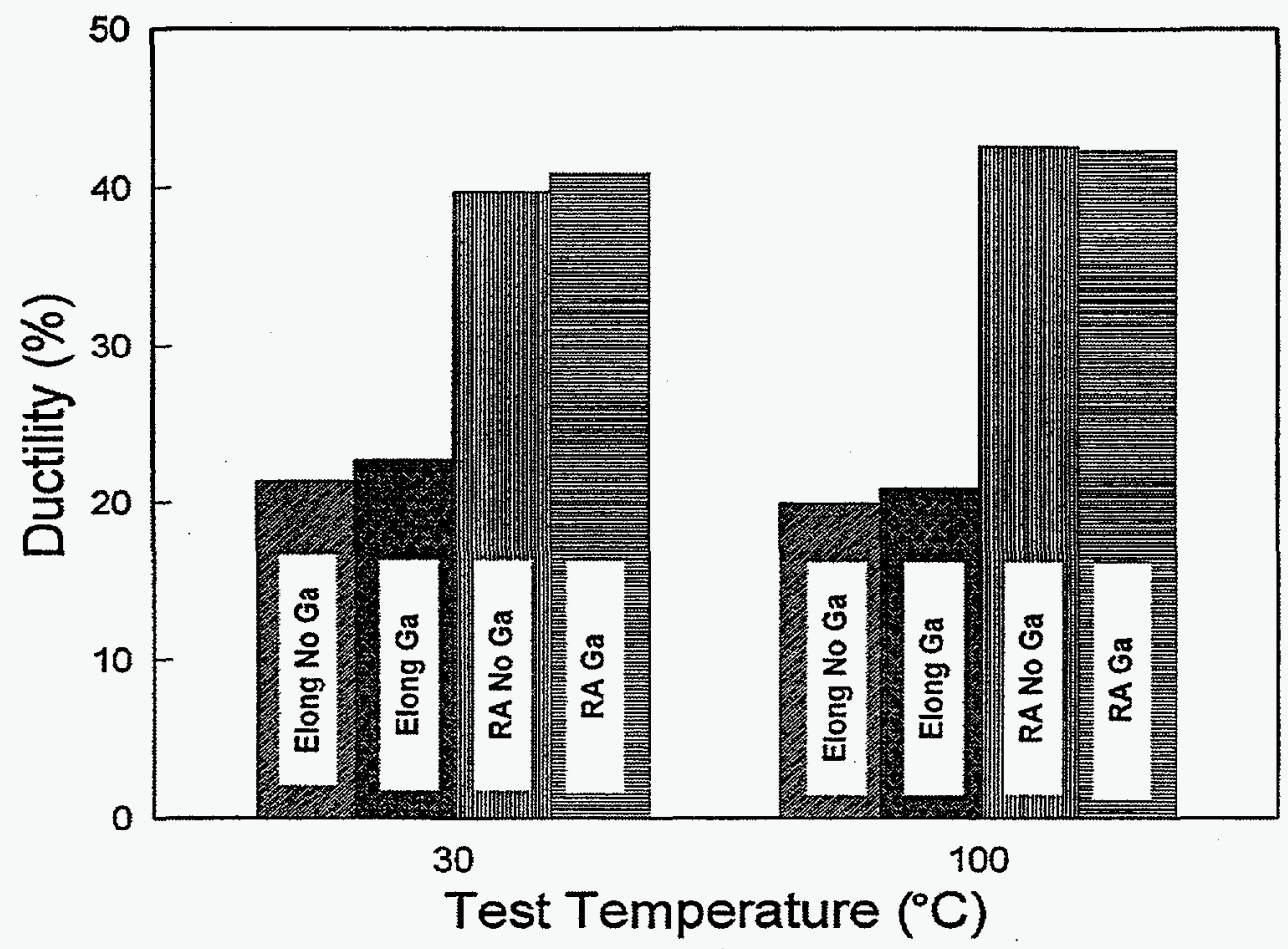

Fig. 9. No significant difference in ductility at 30 and $100^{\circ} \mathrm{C}$. Elong, elongation; $\mathrm{RA}$, reduction in cross sectional area. 


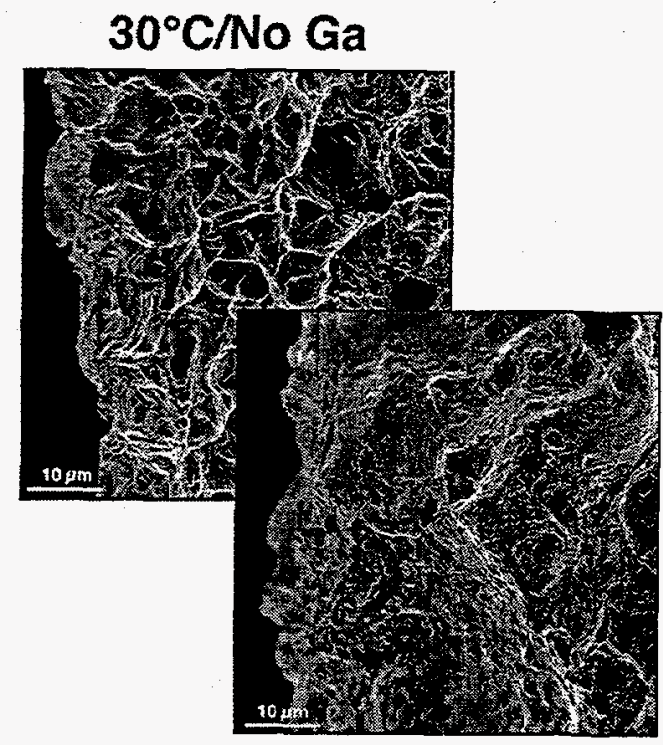

$30^{\circ} \mathrm{C} / \mathrm{Ga}$

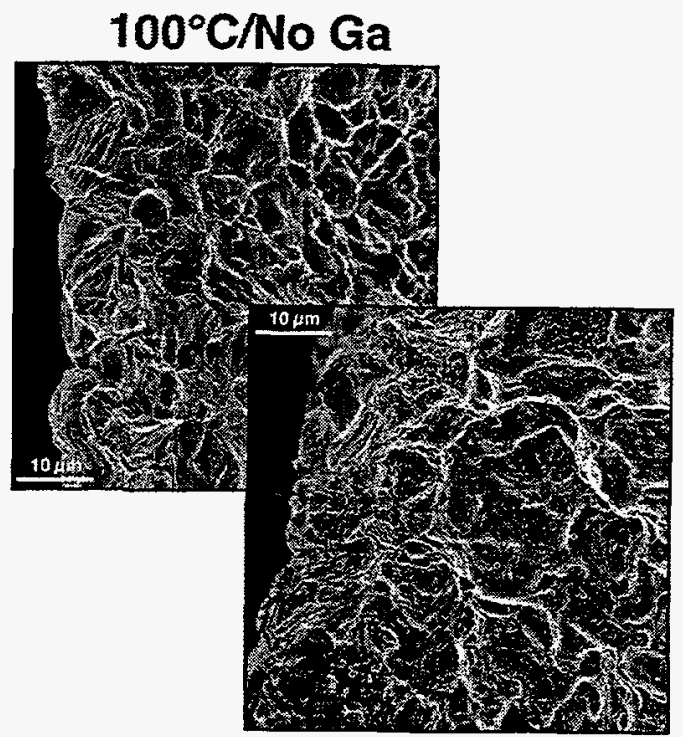

$100^{\circ} \mathrm{C} / \mathrm{Ga}$

Fig. 10. Ductile failure mode at 30 and $100^{\circ} \mathrm{C}$ with and without gallium.

\subsubsection{Corrosion-Mechanical Tests}

The purpose of these tests was to obtain some measure of the effect of ICF on the mechanical properties of Zircaloy. The $\mathrm{Zr}_{\mathrm{x}} \mathrm{Ga}_{\mathrm{y}} \mathrm{IC}$ is quite hard and brittle; therefore, significant ICF would be expected to markedly affect the mechanical properties of the Zircaloy.

Furthermore, as reported previously, distortion of Zircaloy at $500^{\circ} \mathrm{C}$ became a complicating factor. Based on prior data from the corrosion tests, exposure of the Zircaloy to gallium for $30 \mathrm{~h}$ at $300^{\circ} \mathrm{C}$ was ultimately selected as the condition for the corrosion portion of the corrosion-mechanical tests. Under these conditions, most of the gallium did not react with the Zircaloy; however, a thin, intermittent area of ICF was present along the gage length of the Zircaloy capsule specimen. Tensile properties were then measured at room temperature and at $300^{\circ} \mathrm{C}$. The results (average of three specimens per material, per condition) are shown in Figs. 11 and 12 and indicate very little, if any, effect of the formation of small amounts of ICF on the mechanical properties of Zircaloy. In addition, examination of the fracture surfaces did not indicate any significant difference in the mode of failure (Fig. 13). 


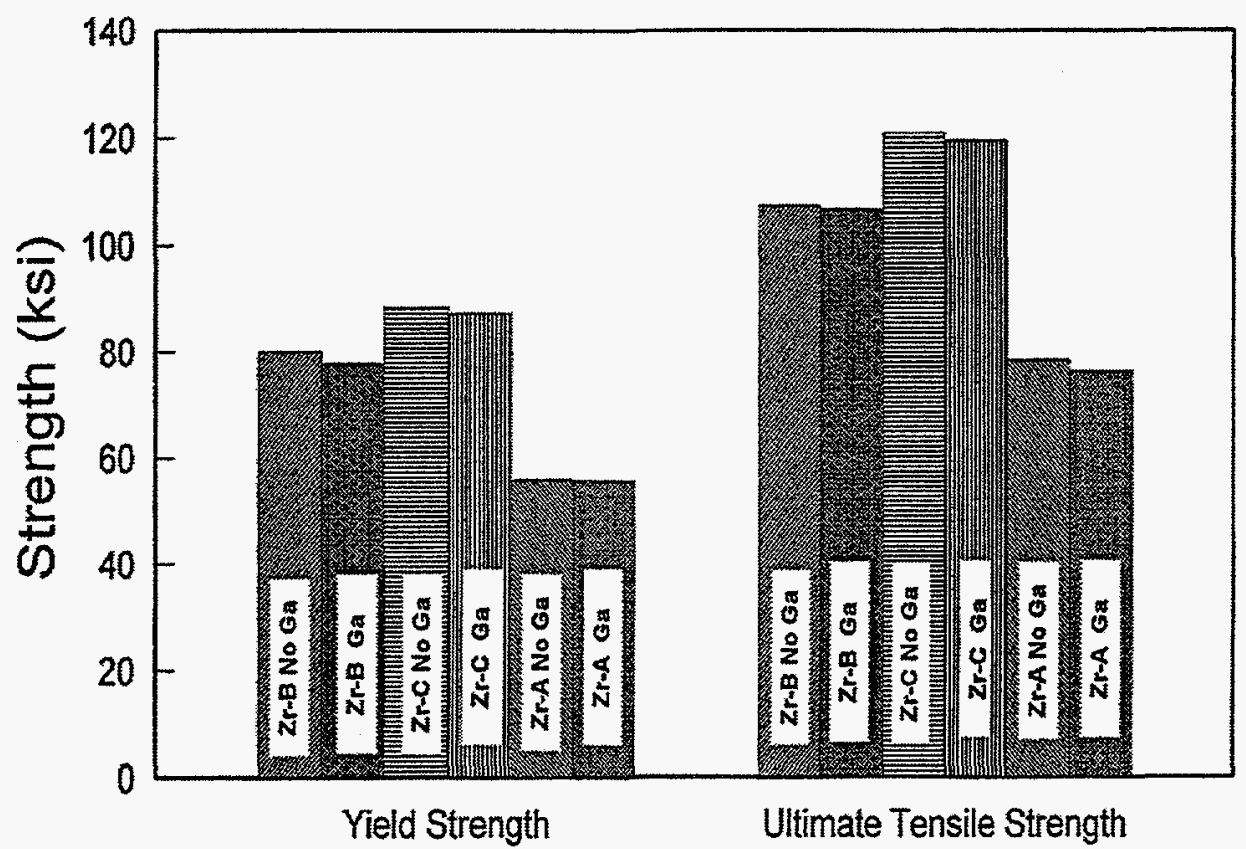

Fig. 11. No change in strength after reaction with gallium for $30 \mathrm{~h}$ at $300^{\circ} \mathrm{C}$.

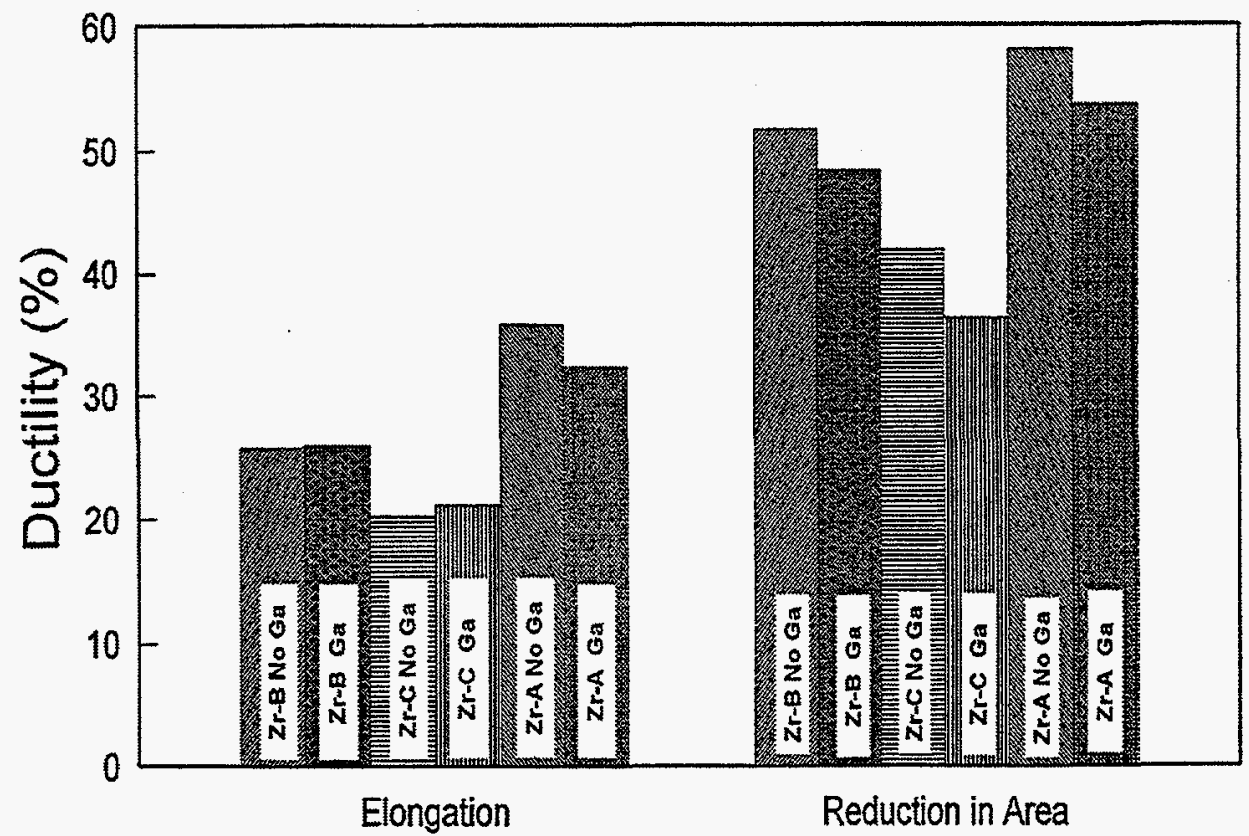

Fig. 12. No significant change in ductility after exposure to gallium for 30 h at $300^{\circ} \mathrm{C}$. 


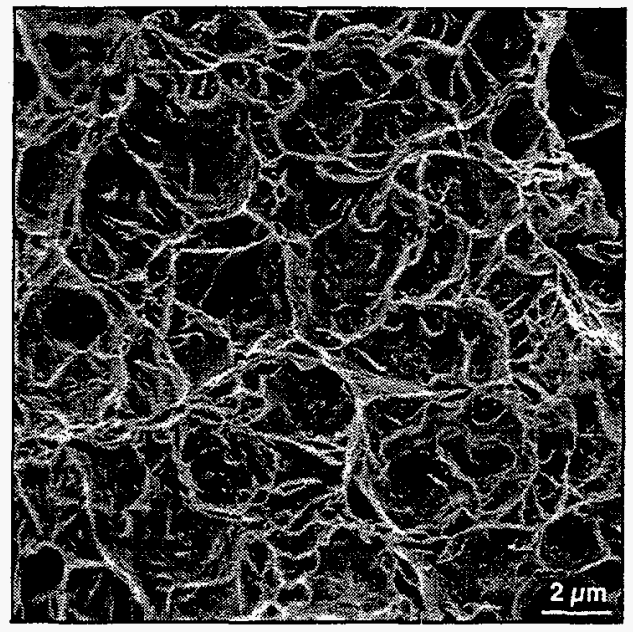

No Gallium

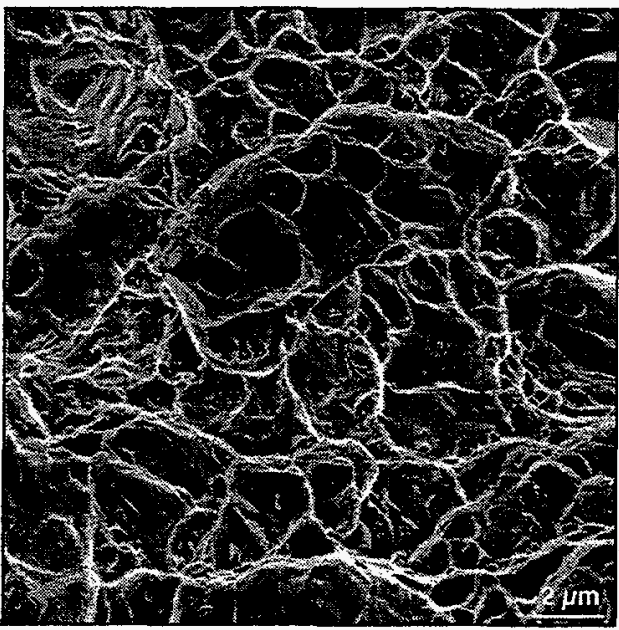

Gallium

Fig. 13. Ductile fracture observed after $30 \mathrm{~h}$ at $300^{\circ} \mathrm{C}$ without and with gallium. Specimen mechanically tested at room temperature.

\subsection{PHASE II}

\subsubsection{Corrosion Tests}

Corrosion tests in $\mathrm{Ga}_{2} \mathrm{O}_{3}$ powder were conducted at 300,500 , and $700^{\circ} \mathrm{C}$ for 6 and 12 weeks. $\mathrm{Ce}_{2} \mathrm{O}_{3}$ powder was mechanically blended with $\mathrm{Ga}_{2} \mathrm{O}_{3}$ powder to produce mixtures that contained $100,1,0.2$, and $0.1 \mathrm{wt} \% \mathrm{Ga}_{2} \mathrm{O}_{3}$ to assess the effect of concentration of gallium present during the exposures.

Before initiating these tests, several surrogate oxides (for $\mathrm{PuO}_{2}$ ) were tested at 500 or $700^{\circ} \mathrm{C}$ with Zircaloy: $\mathrm{ZrO}_{2}, \mathrm{CaO}$, and $\mathrm{Ce}_{2} \mathrm{O}_{3}$, as well as $\mathrm{Ga}_{2} \mathrm{O}_{3}$. In all cases, as would also occur with $\mathrm{PuO}_{2},{ }^{1}$ an oxide layer was found on the inner surface of the Zircaloy that was qualitatively identified as $\mathrm{ZrO}_{2}$ (Fig. 14).

In the matrix tests, there were significant differences among results at the three temperatures. At $300^{\circ} \mathrm{C}$, no significant reaction was noted except for very slight surface roughening, even after the 12-week exposures (Fig. 15). At $500^{\circ} \mathrm{C}$, the oxide layer mentioned previously was observed in all of the tests (Fig. 16). The thickness of the oxide layer was independent of $\mathrm{Ga}_{2} \mathrm{O}_{3}$ concentration and did not appreciably increase with time between 6 and 12 weeks. A distinguishable zone can be noted below the oxide layer. Although this zone was larger for the tests with $100 \%\left(\mathrm{Ga}_{2} \mathrm{O}_{3}\right.$, there was no appreciable difference among $1,0.2$, and $0.1 \% \mathrm{Ga}_{2} \mathrm{O}_{3}$ exposures. 

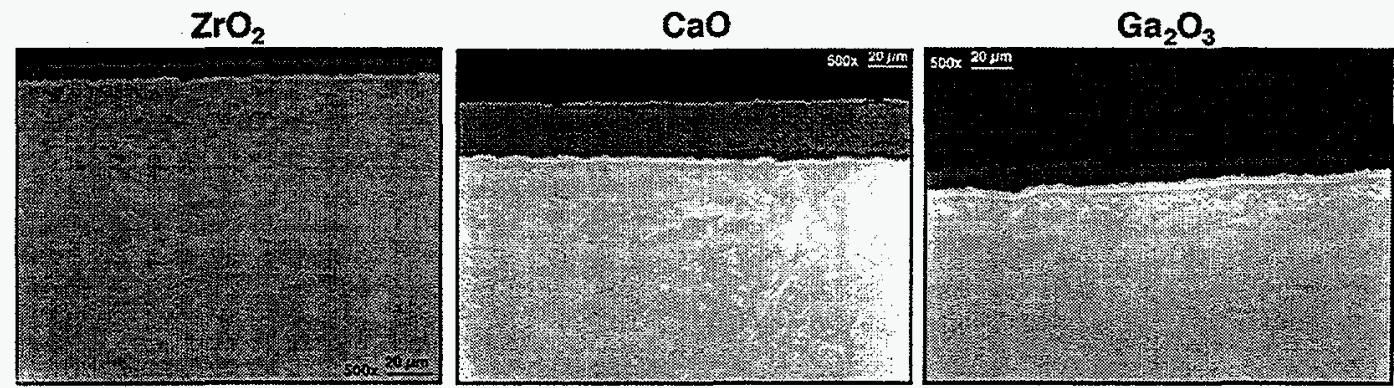

Fig. 14. Zircaloy reacts with oxides at $500^{\circ} \mathrm{C}$ to form zirconium oxide. Zirconium oxide formation is not limited to reaction of Zircaloy with $\mathrm{Ga}_{2} \mathrm{O}_{3}$.
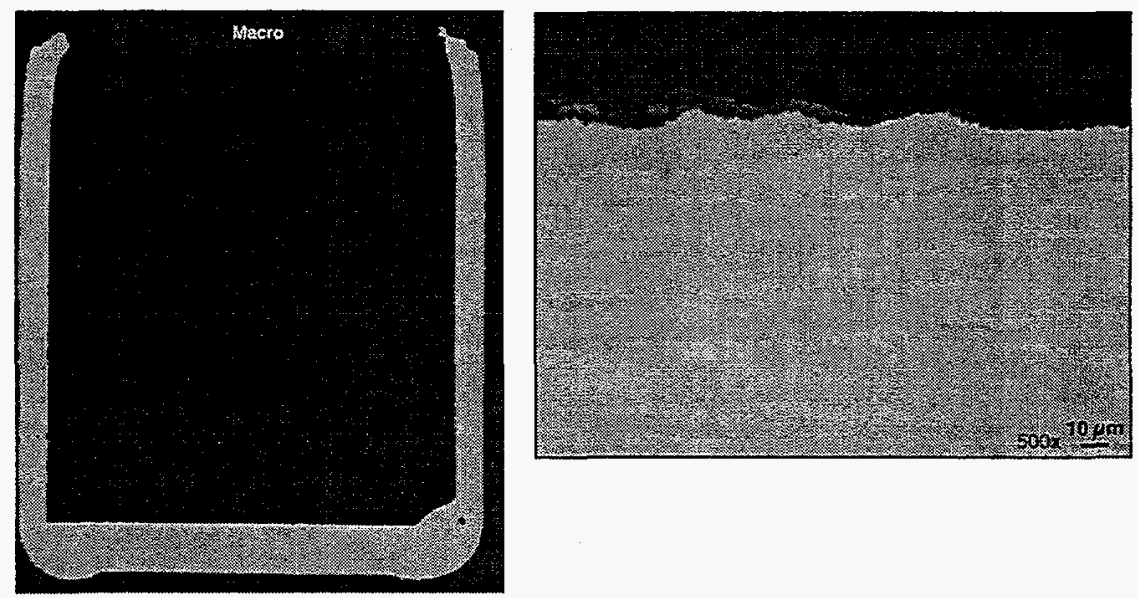

Fig. 15. No significant reaction of Zircaloy with $\mathrm{Ga}_{2} \mathrm{O}_{3}$ after 12 weeks at $300{ }^{\circ} \mathrm{C}$. 


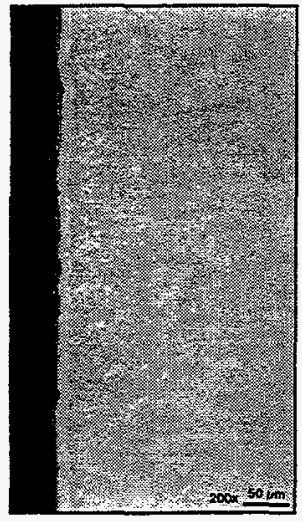

GS-71 $100 \%$
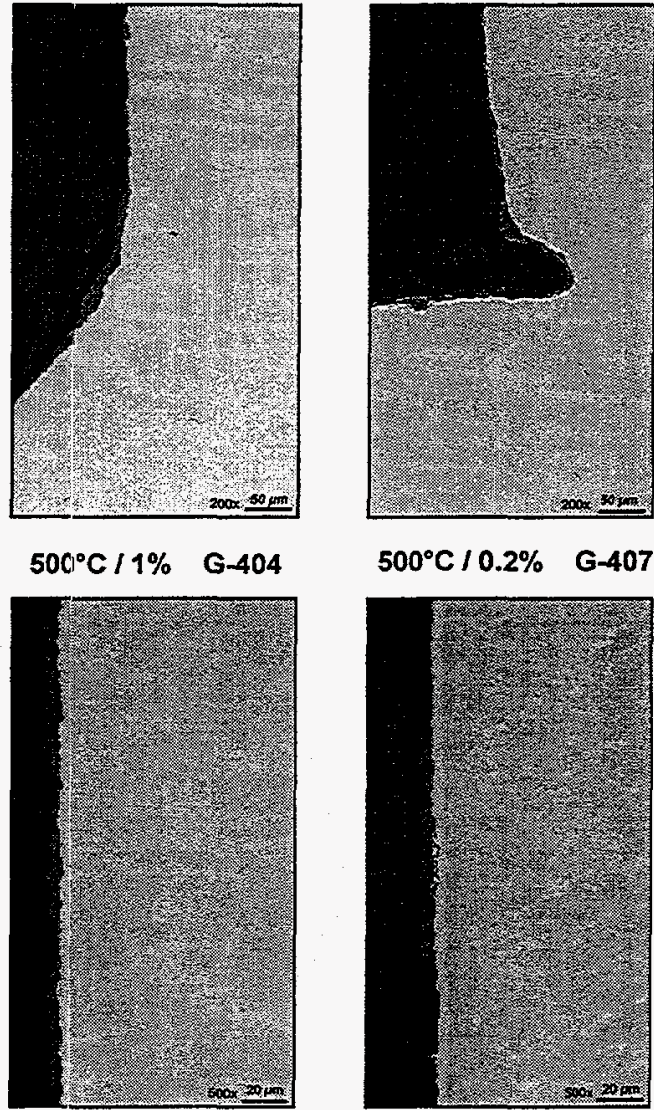

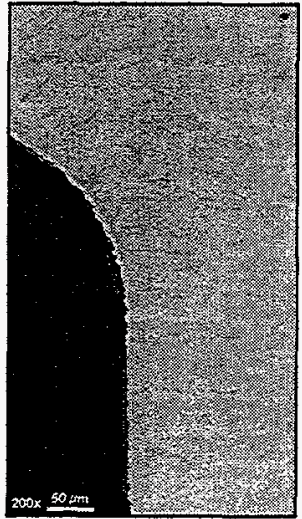

$500^{\circ} \mathrm{C} / 0.1 \% \quad \mathrm{G}-410$

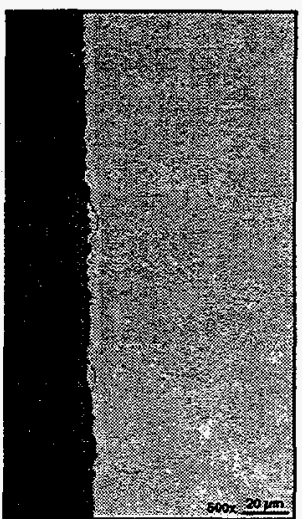

Fig. 16. Oxide layer present at $500^{\circ} \mathrm{C}$ for all ratios of $\mathrm{Ga}_{2} \mathrm{O}_{3}$ to cerium oxide.

At $700^{\circ} \mathrm{C}$, there was formation of an oxide layer on the inner surface of the Zircaloy and an identifiable gallium-rich zone below the oxide layer. The thickness of both the oxide and gallium-rich zone increased with time, but the gallium-rich zone was visible only with $100 \%$ $\mathrm{Ga}_{2} \mathrm{O}_{3}$ (Fig. 17). Another feature not seen at $500^{\circ} \mathrm{C}$ is cracking of the Zircaloy. Generally, testing at $700^{\circ} \mathrm{C}$ resulted in a somewhat uniform distortion of the Zircaloy tubing, and the cracks may be associated with an oxygen-enriched zone. 


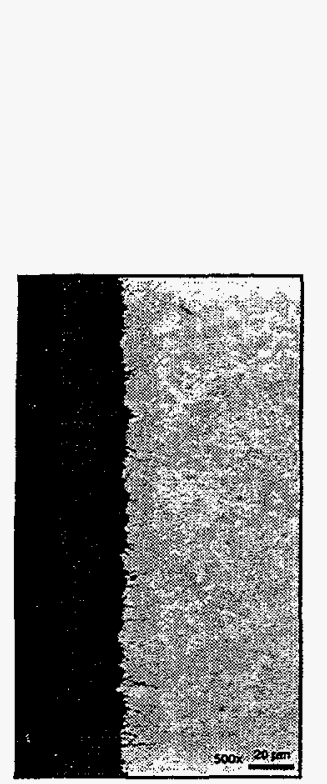

GS-74 100\%
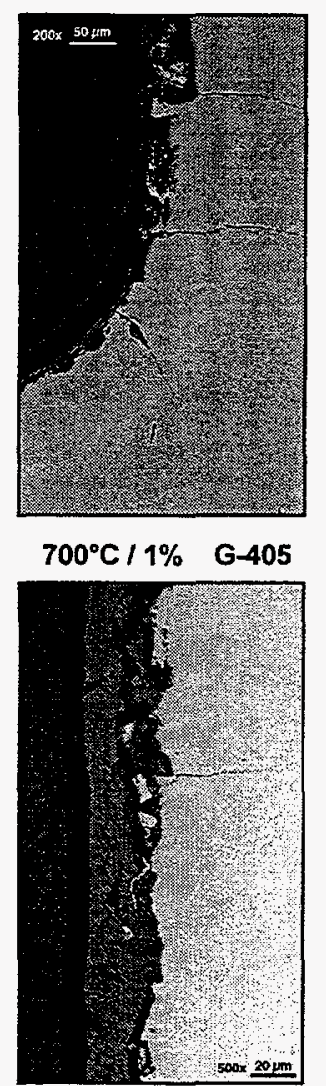
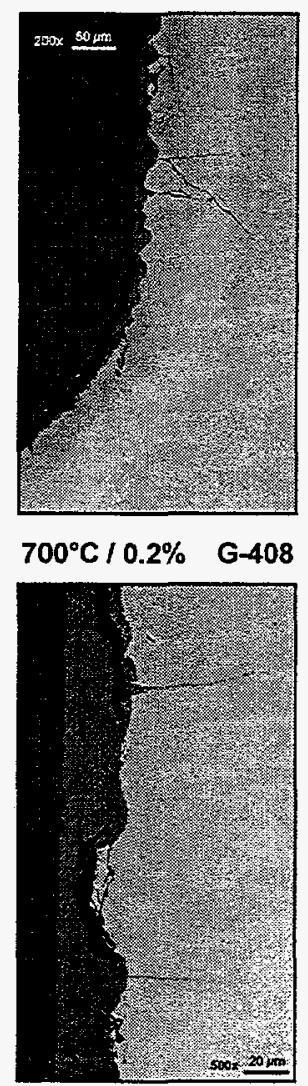

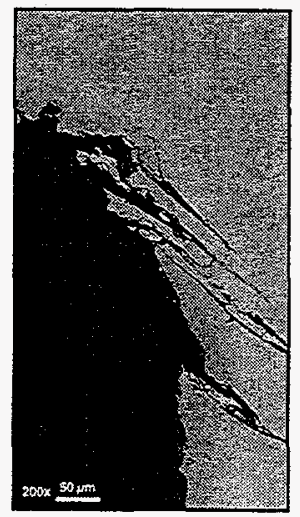

$700^{\circ} \mathrm{C} / 0.1 \% \quad \mathrm{G}-411$

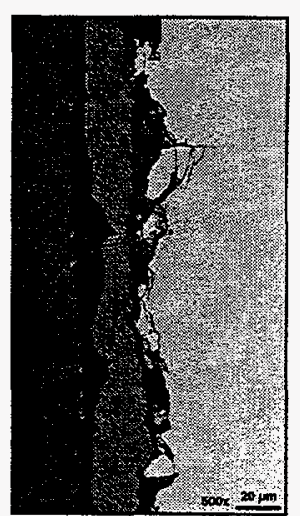

Fig. 17. $\mathrm{Zr}_{\mathbf{x}} \mathrm{Ga}_{\mathbf{y}}$ identified below the zirconium oxide layer after exposure to $100 \% \mathrm{Ga}_{2} \mathrm{O}_{3}$ at $700^{\circ} \mathrm{C}$.

\subsubsection{Corrosion-Mechanical Tests}

This portion of the testing program is ongoing, and results thus far are available only for corrosion testing at 300 and $500^{\circ} \mathrm{C}$ with one of the Zircaloy materials. As shown in Figs. 18 and 19 , there was no change in the room temperature tensile properties (three specimens per condition) of Zircaloy after exposure at $300^{\circ} \mathrm{C}$, as would have been predicted based on the corrosion test results reported previously. At $500^{\circ} \mathrm{C}$, a decrease in both room temperature yield and ultimate tensile strength was measured for all $\mathrm{Ga}_{2} \mathrm{O}_{3}$ concentrations, with a corresponding increase in ductility as measured by elongation and reduction in area. Control tests are in progress to determine whether these changes are a result of heat treatment at $500^{\circ} \mathrm{C}$ instead of the test environment. Mechanical testing after exposure at $700^{\circ} \mathrm{C}$ was not possible because of distortion during the $700^{\circ} \mathrm{C}$ exposure. 


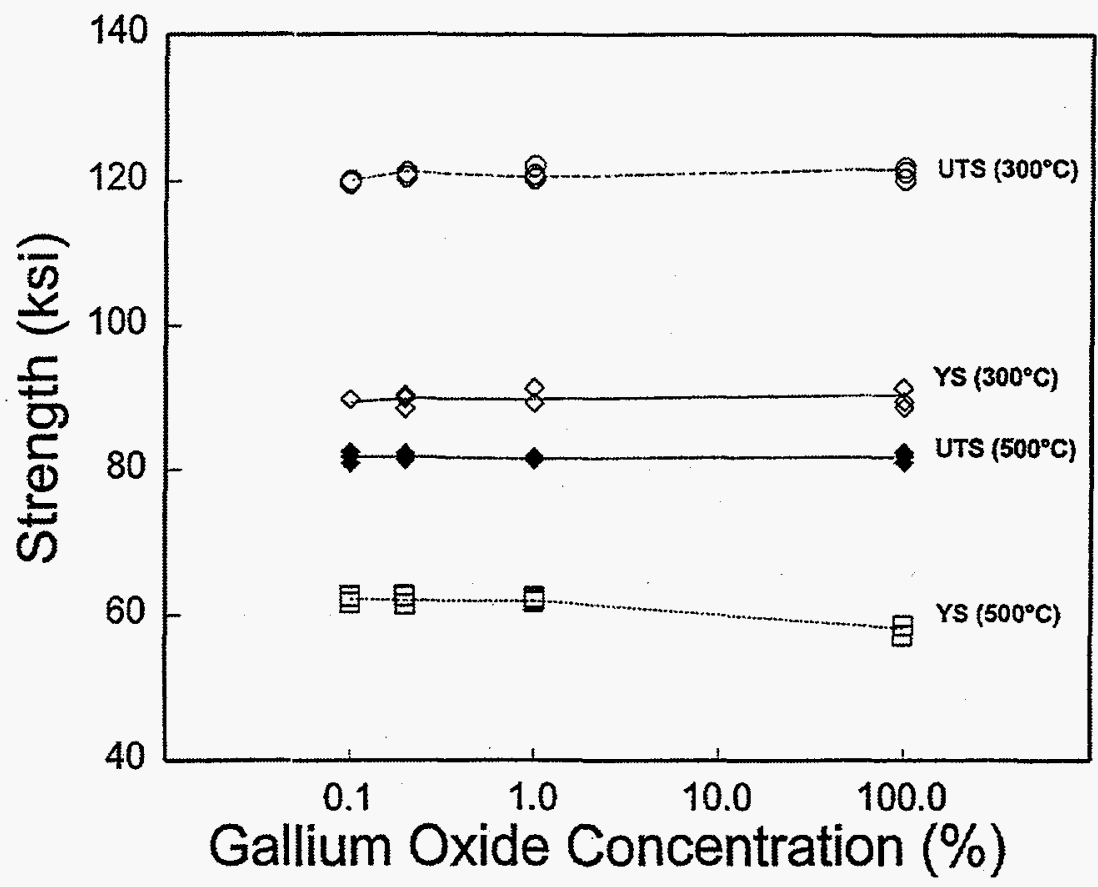

Fig. 18. No significant change in strength after exposure to $\mathrm{Ga}_{2} \mathrm{O}_{3}$ in cerium oxide ( 6 weeks at 300 and $500^{\circ} \mathrm{C}$ ). YS, yield strength; UTS, ultimate tensile strength.

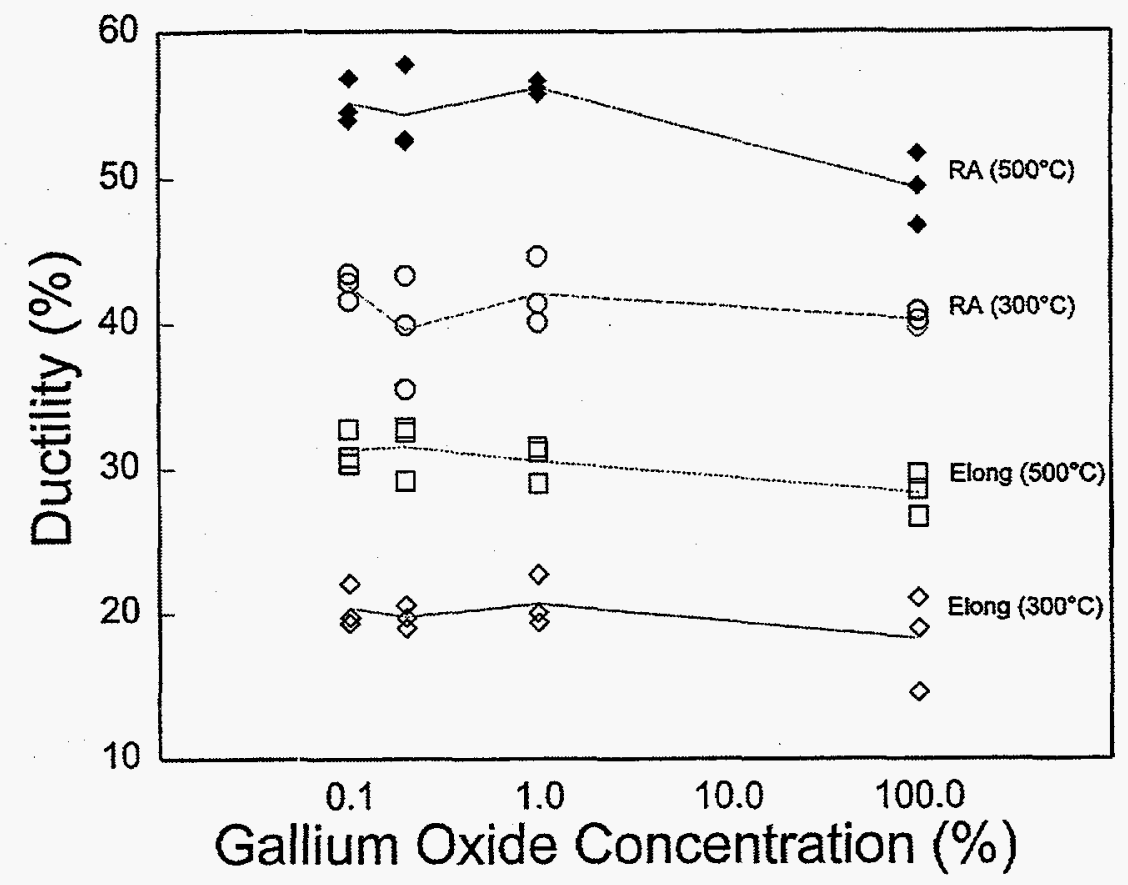

Fig. 19. No significant change in ductility after exposure to $\mathrm{Ga}_{2} \mathrm{O}_{3}$ in cerium oxide ( 6 weeks at 300 and $500^{\circ} \mathrm{C}$ ). Elong, elongation; RA, reduction in cross sectional area. 


\section{CONCLUSIONS}

\subsection{PHASE I}

Corrosion testing revealed that liquid gallium reacts with Zircaloy to form an IC of the form $\mathrm{Zr}_{\mathrm{x}} \mathrm{Ga}_{\mathrm{y}}$. The extent of reaction is a function of temperature, but more importantly, is strongly dependent on the amount of gallium involved. Although distortion of Zircaloy can be a by-product of ICF at $>300^{\circ} \mathrm{C}$, distortion at $500^{\circ} \mathrm{C}$ did not occur at ratios of weight of gallium to surface area of Zircaloy that were $10^{4}$ to $10^{5}$ higher than expected with WG-MOX fuel in an LWR fuel pin. Mechanical property testing after corrosion exposure to form a thin IC layer on the gage section of Zircaloy specimens further confirmed there should be little effect of small quantities of gallium in MOX fuel on the Zircaloy cladding.

No localized corrosion effects have been found. In the corrosion tests (up to $500^{\circ} \mathrm{C}$ ), there was no evidence of grain boundary attack in addition to ICF. In the LME tests at 30 and $100^{\circ} \mathrm{C}$, there was no change in the tensile properties when Zircaloy was tested in liquid gallium and the fracture remained ductile.

\subsection{PHASE II}

Results of testing in $\mathrm{Ga}_{2} \mathrm{O}_{3}$ or $\mathrm{Ce}_{2} \mathrm{O}_{3}-\mathrm{Ga}_{2} \mathrm{O}_{3}$ mixtures have not indicated any significant effects at $300^{\circ} \mathrm{C}$. At $500^{\circ} \mathrm{C}$, an oxide layer formed on the Zircaloy and room temperature tensile tests showed a slight loss in strength with a corresponding increase in ductility. The oxide layer formed during exposure of Zircaloy to several other oxide powders, making it uncertain whether any mechanical effects are related to the presence of gallium. Further testing and analysis are in progress.

At $700^{\circ} \mathrm{C}$, which is considerably above LWR operating temperatures, there is evidence of reduction of $\mathrm{Ga}_{2} \mathrm{O}_{3}$ by Zircaloy and formation of a gallium-rich corrosion product below the ubiquitous oxide layer. However, this gallium-rich zone has not yet been affirmed in tests with $<100 \% \mathrm{Ga}_{2} \mathrm{O}_{3}$. Testing and analysis on this issue are still in progress.

Even though testing and evaluation are still in progress, based on the results obtained thus far, it does not appear that 1 to $10 \mathrm{ppm}$ gallium in MOX fuel will have any measurable effect on the properties of Zircaloy cladding. 



\section{REFERENCES}

1. D. F. Wilson et al., Potential Effects of Gallium on Cladding Materials, ORNL/TM-13504, Lockheed Martin Energy Research Corp., Oak Ridge Natl. Lab., 1997.

2. D. F. Wilson et al, Interactions of Zircaloy Cladding with Gallium 1997 Status, ORNL/TM13505, Lockheed Martin Energy Research Corp., Oak Ridge Natl. Lab., 1997.

3. T. B. Massalski, ed., Binary Alloy Phase Diagrams 2, p. 1880, ASM International, Metals Park, Ohio, 1990.

4. H. S. Rosenbaum, Electrochemical Technology 4, 153 (1966).

5. H. S. Rosenbaum, J. H. Davies, and J. Q. Pon, EURAEC Report, GEAP 5100-5105, 1966.

6. W. T. Grubb, "Cadmium Embrittlement of Zircaloy-2 and Certain Other Metals and Alloys," pp. 473-484 in Embrittlement by Liquid and Solid Metals, ed. M . H. Kamdar. The Metallurgical Society of AIME, Warrendale, Penn., 1984.

7. R. P. Gangloff, "Solid Cadmium Embrittlement of Textured Zircaloy-2," pp. 485-505 in Embrittlement by Liquid and Solid Metals, ed. M. H. Kamdar. The Metallurgical Society of AIME, Warrendale, Penn., 1984.

8. B. Cox, Environmentally Induced Cracking of Zirconium Alloys: II-Liquid Metal Embrittlement, AECL-3612, Atomic Energy of Canada, Ontario, Canada, 1970.

9. T. Watanabe, S. Shima, and S. Karashima, "Liquid Metal Gallium Induced Intergranular Fracture of Aluminum Bicrystals," pp. 173-182 in Embrittlement by Liquid and Solid Metals, ed. M. H. Kamdar. The Metallurgical Society of AIME, Warrendale, Penn., 1984.

10. H. Ichinose and T. Takashima, "Grain Boundary Diffusion and Static Fatigue of Aluminum by Liquid Gallium," pp. 197-210 in Embrittlement by Liquid and Solid Metals, ed. M . H. Kamdar. The Metallurgical Society of AIME, Warrendale, Penn., 1984.

11. W. T. Grubb and M. H. Morgan III, "A Survey of Chemical Environments for Activity in the Embrittlement of Zircaloy-2," Proceedings of the Fourth International Conference: Zirconium in the Nuclear industry, 145-154, ASTM STP 681, American Society for Testing and Materials, Philadelphia, Penn., 1979.

12. H. R. Trellue et al., Nuclecr Fuels Technologies Fiscal Year 1997 Research and Development Test Results, LA-UR-97-4423, Univ. of Calif., Los Alamos Natl. Lab., 1997. 


\begin{abstract}
APPENDIX
The following tables summarize the status of the work performed. Non-vendor-supplied materials are listed with their trade names. Vendor-supplied materials are listed with generic names.
\end{abstract}

Table A.1. Additional compatibility tests of zirconium/Zircaloy with gallium or $\mathbf{G a}_{2} \mathbf{O}_{3}$

\begin{tabular}{|c|c|c|c|c|}
\hline Material & $\begin{array}{c}\begin{array}{c}\text { Test } \\
\text { environment }\end{array} \\
\end{array}$ & $\begin{array}{l}\text { Temp. } \\
\left({ }^{\circ} \mathrm{C}\right)\end{array}$ & $\begin{array}{c}\text { Time } \\
\text { (h) }\end{array}$ & Comments \\
\hline $\mathrm{Zr}$ & $\mathrm{Ga}$ & 400 & 100 & Intermetallic compound formation (ICF) \\
\hline $\mathrm{Zr}$ & $\mathrm{Ga}$ & 600 & 134 & ICF \\
\hline Zircaloy-2 & $\mathrm{Ga}$ & 400 & 100 & ICF \\
\hline Zircaloy-2 & $\mathrm{Ga}$ & 600 & 100 & ICF \\
\hline Zircaloy-2 & $\mathrm{Ga}_{2} \mathrm{O}_{3}$ & 400 & 200 & Thin $\mathrm{ZrO}_{2}$ layer visible at $1000 \mathrm{X}$ \\
\hline Zircaloy-2 & $\mathrm{Ga}_{2} \mathrm{O}_{3}$ & 600 & 200 & Slightly thicker $\mathrm{ZrO}_{2}$ layer visible at $1000 \mathrm{X}$ \\
\hline Zircaloy-2 & $\mathrm{Ga}_{2} \mathrm{O}_{3}$ & 500 & 672 & $\mathrm{ZrO}_{2}$ layer plus $\mathrm{Ga}$ within alloy \\
\hline Zircaloy-2 & $\mathrm{Ga}_{2} \mathrm{O}_{3}$ & 500 & 2016 & $\begin{array}{l}\mathrm{ZrO}_{2} \text { layer plus Ga within alloy; no change } \\
\text { in thickness (compared with } 4 \text { weeks) }\end{array}$ \\
\hline Zircaloy-4 & $\mathrm{Ga}_{2} \mathrm{O}_{3}$ & 700 & 672 & $\begin{array}{l}\text { Much thicker } \mathrm{ZrO}_{2} \text { layer (compared with } \\
500^{\circ} \mathrm{C} \text { ) plus ICF below oxide; cracks in } \\
\mathrm{ZrO}_{2}\end{array}$ \\
\hline Zircaloy-4 & $\mathrm{Ga}_{2} \mathrm{O}_{3}$ & 700 & 2016 & $\begin{array}{l}4 \text { mil } \mathrm{ZrO}_{2} \text { layer plus } 3 \text { mils of ICF below } \\
\text { oxide }\end{array}$ \\
\hline Zircaloy-B (vendor) & Ga & 500 & 200 & $\begin{array}{l}\text { Electron beam welding (EBW) (vacuum); } \\
\text { ICF; very slight distortion }\end{array}$ \\
\hline Zircaloy-C (vendor) & $\mathrm{Ga}$ & 500 & 200 & EBW (vacuum); ICF; distortion \\
\hline Zircaloy-B (vendor) & $\mathrm{Ga}$ & 500 & 200 & $\begin{array}{l}\text { Thin end cap ( } 0.50 \text { in.); ICF; very slight } \\
\text { distortion }\end{array}$ \\
\hline Zircaloy-B (vendor) & $\mathrm{Ga}$ & 500 & 200 & $\begin{array}{l}\text { Thick end cap ( } 0.2 \text { in.) with circumferential } \\
\text { laser beam welding (LBW) of end cap to } \\
\text { seal crevice; ICF; distortion }\end{array}$ \\
\hline Zircaloy-C (vendor) & $\mathrm{Ga}$ & 500 & 200 & Thin end cap; ICF; distortion \\
\hline Zircaloy-C (vendor) & $\mathrm{Ga}$ & 500 & 200 & Thick end cap with LBW; ICF; distortion \\
\hline Zircaloy-C (vendor) & Ga & 500 & 200 & $\sim 650$ ppm Ga in $\mathrm{ZrO}_{2}$ powder \\
\hline Zircaloy-C (vendor) & $\mathrm{Ga}$ & 500 & 200 & $\begin{array}{l}\sim 650 \mathrm{ppm} \mathrm{Ga} \text { at bottom of capsule covered } \\
\text { with } \mathrm{ZrO}_{2} \text { powder }\end{array}$ \\
\hline Zircaloy-4 & $\mathrm{Ga}_{2} \mathrm{O}_{3}$ & 700 & 672 & $\begin{array}{l}\sim 1800 \mathrm{ppm} \mathrm{Ga} \mathrm{O}_{3} \text { blended with } \mathrm{ZrO}_{2} \\
\text { interaction to }<0.5 \text { mil }\end{array}$ \\
\hline Zircaloy-C (vendor) & $\mathrm{ZrO}_{2}$ & 500 & 200 & $\mathrm{ZrO}_{2}$ as surrogate \\
\hline
\end{tabular}


Table A.1. Additional compatibility tests of zirconium/Zircaloy with gallium or $\mathrm{Ga}_{2} \mathrm{O}_{3}$

\begin{tabular}{|c|c|c|c|c|}
\hline Material & $\begin{array}{c}\text { Test } \\
\text { environment }\end{array}$ & $\begin{array}{l}\text { Temp. } \\
\left({ }^{\circ} \mathrm{C}\right)\end{array}$ & $\begin{array}{c}\text { Time } \\
\text { (h) }\end{array}$ & Comments \\
\hline Zircaloy-C (vendor) & $\mathrm{CaO}$ & 500 & 200 & $\mathrm{CaO}$ as surrogate \\
\hline Zircaloy-B (vendor) & $\mathrm{Ce}_{2} \mathrm{O}_{3}$ & 500 & 200 & $\mathrm{Ce}_{2} \mathrm{O}_{\hat{3}}$ as surrogate \\
\hline Zircaloy-B (vendor) & $\mathrm{Ga}$ & 500 & 200 & $\begin{array}{l}3 \mathrm{~g} \mathrm{Ga} \text {; evaluation of } \mathrm{W} \text { insert geometry for } \\
\text { LME \& C-M tests }\end{array}$ \\
\hline Zircaloy-C (vendor) & $\mathrm{Ga}$ & 500 & 200 & $\begin{array}{l}3 \mathrm{~g} \mathrm{Ga} \text {; evaluation of } \mathrm{W} \text { insert geometry for } \\
\text { LME \& C-M tests }\end{array}$ \\
\hline Zircaloy-C (vendor) & - & & & $\begin{array}{l}\text { No insert; evaluation of specimen geometry } \\
\text { for LME \& C-M tests }\end{array}$ \\
\hline Zircaloy-C (vendor) & $\mathrm{Ga}$ & & & $\begin{array}{l}\text { Large insert; evaluation of } W \text { insert for } \\
\text { LME \& C-M tests }\end{array}$ \\
\hline Zircaloy-C (vendor) & $\mathrm{Ga}$ & & & $\begin{array}{l}\text { No insert; evaluation of specimen geometry } \\
\text { for LME \& C-M tests }\end{array}$ \\
\hline Zircaloy-C (vendor) & $\mathrm{Ga}$ & & & $\begin{array}{l}\text { Small insert; evaluation of } W \text { insert for } \\
\text { LME and C-M tests }\end{array}$ \\
\hline Zircaloy-C (vendor) & $\mathrm{Ga}$ & 300 & 200 & $\begin{array}{l}\text { Determine acceptable, } f(\mathrm{~T}) \text {, (no swelling \& } \\
\text { very thin corrosion layer) corrosion } \\
\text { conditions for C-M tests }\end{array}$ \\
\hline Zircaloy-C (vendor) & $\mathrm{Ga}$ & 400 & 200 & $\begin{array}{l}\text { Determine acceptable, } f(T) \text {, (no swelling \& } \\
\text { very thin corrosion layer) corrosion } \\
\text { conditions for C-M tests }\end{array}$ \\
\hline Zircaloy-C (vendor) & $\mathrm{Ga}$ & 350 & 200 & $\begin{array}{l}\text { Determine acceptable, } f(\mathrm{~T}) \text {, (no swelling \& } \\
\text { very thin corrosion layer) corrosion } \\
\text { conditions for C-M tests }\end{array}$ \\
\hline Zircaloy-B (vendor) & $\mathrm{Ga}$ & 300 & 100 & $\begin{array}{l}\text { Determine acceptable, } f(t) \text {, (no swelling \& } \\
\text { and very thin corrosion layer) corrosion } \\
\text { conditions for C-M tests }\end{array}$ \\
\hline Zircaloy-B (vendor) & $\mathrm{Ga}$ & 300 & 25 & $\begin{array}{l}\text { Determine acceptable, } f(\mathrm{t}) \text {, (no swelling \& } \\
\text { very thin corrosion layer) corrosion } \\
\text { conditions for C-M tests }\end{array}$ \\
\hline Zircaloy-B (vendor) & $\mathrm{Ga}$ & 300 & 50 & $\begin{array}{l}\text { Determine acceptable, } f(\mathrm{t}) \text {, (no swelling \& } \\
\text { very thin corrosion layer) corrosion } \\
\text { conditions for C-M tests }\end{array}$ \\
\hline Zircaloy-A (vendor) & $\mathrm{Ga}$ & 500 & 200 & Comparison of distortion, $f$ (material) \\
\hline Zircaloy-B (vendor) & $\mathrm{Ga}$ & 500 & 200 & Comparison of distortion, $f$ (material) \\
\hline Zircaloy-C (vendor) & $\mathrm{Ga}$ & 500 & 200 & Comparison of distortion, $f$ (material) \\
\hline Zircaloy-A (vendor) & $\mathrm{Ga} / \mathrm{Cd}$ & 500 & 200 & Comparison of distortion, $f$ (material) \\
\hline Zircaloy-B (vendor) & $\mathrm{Ga} / \mathrm{Cd}$ & 500 & 200 & Comparison of distortion, $f$ (material) \\
\hline Zircaloy-C (vendor) & $\mathrm{Ga} / \mathrm{Cd}$ & 500 & 200 & Comparison of distortion, $f$ (material) \\
\hline Zircaloy-A (vendor) & $\mathrm{Ga}$ & 500 & 200 & $\begin{array}{l}25 \mathrm{mg} \mathrm{Ga} \text {; demonstrate amount of attack } \\
\text { with decreasing Ga mass }\end{array}$ \\
\hline Zircaloy-B (vendor) & $\mathrm{Ga}$ & 500 & 200 & $\begin{array}{l}25 \mathrm{mg} \mathrm{Ga} \text {; demonstrate amount of attack } \\
\text { with decreasing Ga mass }\end{array}$ \\
\hline
\end{tabular}


Table A.1. Additional compatibility tests of zirconium/Zircaloy with gallium or $\mathrm{Ga}_{2} \mathrm{O}_{3}$

\begin{tabular}{|c|c|c|c|c|}
\hline Material & $\begin{array}{c}\text { Test } \\
\text { environment } \\
\end{array}$ & $\begin{array}{l}\text { Temp. } \\
\left({ }^{\circ} \mathrm{C}\right)\end{array}$ & $\begin{array}{c}\text { Time } \\
\text { (h) }\end{array}$ & Comments \\
\hline Zircaloy- $C$ (vendor) & $\mathrm{Ga}$ & 500 & 200 & $\begin{array}{l}25 \mathrm{mg} \mathrm{Ga} \text {; demonstrate amount of attack } \\
\text { with decreasing Ga mass }\end{array}$ \\
\hline Zircaloy-A (vendor) & $\mathrm{Ga}$ & 500 & 200 & $\begin{array}{l}2.5 \mathrm{mg} \mathrm{Ga} \text {; demonstrate amount of attack } \\
\text { with decreasing Ga mass }\end{array}$ \\
\hline Zircaloy-B (vendor) & $\mathrm{Ga}$ & 500 & 200 & $\begin{array}{l}2.5 \mathrm{mg} \mathrm{Ga} \text {; demonstrate amount of attack } \\
\text { with decreasing Ga mass }\end{array}$ \\
\hline Zircaloy-C (vendor) & $\mathrm{Ga}$ & 500 & 200 & $\begin{array}{l}2.5 \mathrm{mg} \mathrm{Ga} \text {; demonstrate amount of attack } \\
\text { with decreasing Ga mass }\end{array}$ \\
\hline Zircaloy-A (vendor) & $\mathrm{Ga}$ & 500 & 200 & $\begin{array}{l}0.25 \mathrm{mg} \mathrm{Ga} \text {; demonstrate amount of attack } \\
\text { with decreasing Ga mass }\end{array}$ \\
\hline Zircaloy-B (vendor) & $\mathrm{Ga}$ & 500 & 200 & $\begin{array}{l}0.25 \mathrm{mg} \mathrm{Ga} \text {; demonstrate amount of attack } \\
\text { with decreasing Ga mass }\end{array}$ \\
\hline Zircaloy-C (vendor) & $\mathrm{Ga}$ & 500 & 200 & $\begin{array}{l}0.25 \mathrm{mg} \mathrm{Ga} \text {; demonstrate amount of attack } \\
\text { with decreasing Ga mass }\end{array}$ \\
\hline
\end{tabular}

Table A.2. Status of corrosion tests of Zircaloy with gallium metal

\begin{tabular}{|c|c|c|c|c|c|c|}
\hline \multirow[b]{2}{*}{ Material } & \multirow{2}{*}{$\begin{array}{c}\text { Time } \\
\text { (h) }\end{array}$} & \multicolumn{4}{|c|}{ Temperature $\left({ }^{\circ} \mathrm{C}\right)$} & \multirow[b]{2}{*}{ Comment } \\
\hline & & 30 & 100 & 500 & $500^{*}$ & \\
\hline \multirow{2}{*}{$\begin{array}{l}\text { Zircaloy-A } \\
\text { (vendor) }\end{array}$} & 200 & & & $\checkmark$ & $\checkmark$ & \multirow{2}{*}{$\begin{array}{l}\text { No attack at } 30 \text { or } 100^{\circ} \mathrm{C} \text {; Intermetallic } \\
\text { compound formation (ICF) at } 500^{\circ} \mathrm{C}\end{array}$} \\
\hline & 700 & $\checkmark$ & $\checkmark$ & $\checkmark$ & $\checkmark$ & \\
\hline \multirow[b]{2}{*}{$\begin{array}{l}\text { Zircaloy-B } \\
\text { (vendor) }\end{array}$} & 200 & & & $\checkmark$ & $\checkmark$ & ICF; dimensional distortion \\
\hline & 700 & $\checkmark$ & $\checkmark$ & $\checkmark$ & $\checkmark$ & $\begin{array}{l}\text { No attack at } 30 \text { or } 100^{\circ} \mathrm{C} ; \mathrm{ICF} \text { at } 500^{\circ} \mathrm{C} \\
\text { but no increase over } 200 \mathrm{~h} \text {; dimensional } \\
\text { distortion }\end{array}$ \\
\hline & 200 & & & $\checkmark$ & $\checkmark$ & ICF; dimensional distortion \\
\hline $\begin{array}{l}\text { Zircaloy-C } \\
\text { (vendor) }\end{array}$ & 700 & $\checkmark$ & $\checkmark$ & $\checkmark$ & $\checkmark$ & $\begin{array}{l}\text { No attack at } 30 \text { or } 100^{\circ} \mathrm{C} ; \mathrm{ICF} \text { at } 500^{\circ} \mathrm{C} \\
\text { but no increase over } 200 \mathrm{~h} \text {; dimensional } \\
\text { distortion at } 500^{\circ} \mathrm{C}\end{array}$ \\
\hline
\end{tabular}

"With cadmium.

$\checkmark$ - Completed test.

Table A.3. Status of corrosion tests of Zircaloy with $\mathrm{Ga}_{2} \mathrm{O}_{3}$

\begin{tabular}{lcccccc}
\hline \multirow{2}{*}{ Materials } & $\mathbf{G a}_{2} \mathbf{O}_{3}$ & Time & \multicolumn{3}{c}{ Temperature $\left({ }^{\circ} \mathbf{C}\right)$} & \\
\cline { 5 - 6 } & $(\mathbf{w t} \%)$ & (weeks) & $\mathbf{3 0 0}$ & $\mathbf{5 0 0}$ & $\mathbf{7 0 0}$ & Comment \\
\hline Zircaloy-A & 100 & 6 & $\checkmark$ & $\checkmark$ & $\checkmark$ & \\
(vendor) & 100 & 12 & $\checkmark$ & $\checkmark$ & $\checkmark$ & \\
& 1 & 6 & $\checkmark$ & $\checkmark$ & $\checkmark$ & \\
& 0.2 & 6 & $\checkmark$ & $\checkmark$ & $\checkmark$ & \\
\hline
\end{tabular}


Table A.3. Status of corrosion tests of Zircaloy with $\mathrm{Ga}_{2} \mathrm{O}_{3}$

\begin{tabular}{|c|c|c|c|c|c|c|}
\hline \multirow[b]{2}{*}{ Materials } & \multirow{2}{*}{$\begin{array}{l}\mathrm{Ga}_{2} \mathrm{O}_{3} \\
(\mathrm{wt} \%)\end{array}$} & \multirow{2}{*}{$\begin{array}{c}\text { Time } \\
\text { (weeks) }\end{array}$} & \multicolumn{3}{|c|}{ Temperature $\left({ }^{\circ} \mathrm{C}\right)$} & \multirow[b]{2}{*}{ Comment } \\
\hline & & & 300 & 500 & 700 & \\
\hline \multirow{5}{*}{$\begin{array}{l}\text { Zircaloy-B } \\
\text { (vendor) }\end{array}$} & 100 & 6 & $\checkmark$ & $\checkmark$ & $\checkmark$ & $\begin{array}{l}\text { No interaction at } 300^{\circ} \mathrm{C} ; \mathrm{ZrO}_{2} \text { at } 500 \\
\text { and } 700^{\circ} \mathrm{C} \text {; intermetallic compound } \\
\text { formation }\left(\mathrm{ICF} \text { ) at } 700^{\circ} \mathrm{C}\right.\end{array}$ \\
\hline & 100 & 12 & $\checkmark$ & $\checkmark$ & $\checkmark$ & $\begin{array}{l}\text { Same as for } 6 \text { weeks except greater } \\
\text { depth of interaction at } 700^{\circ} \mathrm{C}\end{array}$ \\
\hline & 1 & 6 & $\checkmark$ & $\checkmark$ & $\checkmark$ & \\
\hline & 0.2 & 6 & $\checkmark$ & $\checkmark$ & $\checkmark$ & \\
\hline & 0.1 & 6 & $\checkmark$ & $\checkmark$ & $\checkmark$ & \\
\hline \multirow{5}{*}{$\begin{array}{l}\text { Zircaloy-C } \\
\text { (vendor) }\end{array}$} & 100 & 6 & $\checkmark$ & $\checkmark$ & $\checkmark$ & $\begin{array}{l}\text { No interaction at } 300^{\circ} \mathrm{C} ; \mathrm{ZrO}_{2} \text { at } 500 \\
\text { and } 700^{\circ} \mathrm{C} \text {; ICF at } 700^{\circ} \mathrm{C}\end{array}$ \\
\hline & 100 & 12 & $\checkmark$ & $\checkmark$ & $\checkmark$ & $\begin{array}{l}\text { Same as for } 6 \text { weeks except greater } \\
\text { depth of interaction at } 700^{\circ} \mathrm{C}\end{array}$ \\
\hline & 1 & 6 & $\checkmark$ & $\checkmark$ & $\checkmark$ & \\
\hline & 0.2 & 6 & $\checkmark$ & $\checkmark$ & $\checkmark$ & \\
\hline & 0.1 & 6 & $\checkmark$ & $\checkmark$ & $\checkmark$ & \\
\hline
\end{tabular}

$\checkmark$-Completed.

Table A.4. Status of mechanical tests of Zircaloy with gallium metal

\begin{tabular}{|c|c|c|c|c|c|c|}
\hline \multirow[b]{2}{*}{ Material } & \multirow[b]{2}{*}{ Type } & \multicolumn{4}{|c|}{ Temperature $\left({ }^{\circ} \mathrm{C}\right)$} & \multirow[b]{2}{*}{ Comment } \\
\hline & & 30 & 100 & 300 & $300^{*}$ & \\
\hline \multirow{2}{*}{$\begin{array}{l}\text { Zircaloy-A } \\
\text { (vendor) }\end{array}$} & LME & $\checkmark$ & $\checkmark$ & & & \\
\hline & $\mathrm{CM}$ & & & $\checkmark$ & $\mathrm{x}$ & \\
\hline \multirow{2}{*}{$\begin{array}{l}\text { Zircaloy-B } \\
\text { (vendor) }\end{array}$} & LME & $\checkmark$ & $\checkmark$ & & & \\
\hline & $\mathrm{CM}$ & & & $\checkmark$ & $\mathrm{x}$ & \\
\hline \multirow{2}{*}{$\begin{array}{l}\text { Zircaloy-C } \\
\text { (vendor) }\end{array}$} & LME & $\checkmark$ & $\checkmark$ & & & \\
\hline & $\mathrm{CM}$ & & & $\checkmark$ & $\mathrm{x}$ & $\begin{array}{l}\text { Fracture surface exhibited nonductile } \\
\text { features }\end{array}$ \\
\hline
\end{tabular}

"With cadmium.

$\checkmark$-Completed test.

LME - Constant extension rate tensile (CERT) test at temperature (triplicate tests).

$\mathrm{CM}$ - CERT test at room temperature after $200 \mathrm{~h}$ at temperature (triplicate tests). 
Table A.5. Status of corrosion-mechanical ${ }^{\star}$ tests of Zircaloy with $\mathrm{Ga}_{2} \mathrm{O}_{3}$

\begin{tabular}{lccccc}
\hline Materials & $\mathrm{Ga}_{2} \mathrm{O}_{3}$ & \multicolumn{5}{c}{ Temperature $\left({ }^{\circ} \mathrm{C}\right)$} & Comment \\
\cline { 5 - 6 } & $(\mathrm{wt} \%)$ & 300 & $\mathbf{5 0 0}$ & $\mathbf{7 0 0}$ & \\
Zircaloy-A & 100 & $\mathrm{x}$ & $\mathrm{x}$ & $\mathrm{x}$ & \\
(vendor) & 1 & $\mathrm{x}$ & $\mathrm{x}$ & $\mathrm{x}$ & \\
& 0.2 & $\mathrm{x}$ & $\mathrm{x}$ & $\mathrm{x}$ & \\
& 0.1 & $\mathrm{x}$ & $\mathrm{x}$ & $\mathrm{x}$ & \\
Zircaloy-B & 100 & $\mathrm{x}$ & $\mathrm{x}$ & $\mathrm{x}$ & \\
(vendor) & $\mathrm{I}$ & $\mathrm{x}$ & $\mathrm{x}$ & $\mathrm{x}$ & \\
& 0.2 & $\mathrm{x}$ & $\mathrm{x}$ & $\mathrm{x}$ & \\
& 0.1 & $\mathrm{x}$ & $\mathrm{x}$ & $\mathrm{x}$ & \\
Zircaloy-C & 100 & $\mathrm{x}$ & $\mathrm{x}$ & $\mathrm{x}$ & \\
(vendor) & 1 & $\mathrm{x}$ & $\mathrm{x}$ & $\mathrm{x}$ & Room temperature tensile testing completed for \\
& 0.2 & $\mathrm{x}$ & $\mathrm{x}$ & $\mathrm{x}$ & preexposure at 300 and $500^{\circ} \mathrm{C}$ \\
& 0.1 & $\mathrm{x}$ & $\mathrm{x}$ & $\mathrm{x}$ & \\
\hline
\end{tabular}

$\mathrm{x}$ - Scheduled.

$\checkmark$-Completed.

${ }^{*}$ Constant extension rate tensile test at room temperature after 6 weeks at temperature (triplicate tests). 